\title{
Kajian Kelayakan dan Pengembangan Desain Teknis Rehabilitasi Pesisir di Sulawesi Tengah
}

Iwan Tri Cahyo Wibisono

Working Paper nr 227 


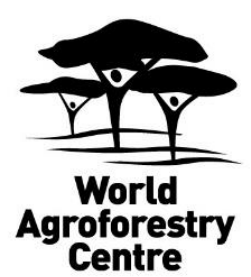

\section{Correct Citation}

Wibisono ITC. 2016. Kajian Kelayakan dan Pengembangan Desain Teknis Rehabilitasi Pesisir. Working paper 227. Bogor, Indonesia: World Agroforestry Centre (ICRAF) Southeast Asia Regional Program. DOI: http://dx.doi.org/10.5716/WP16037.PDF

Titles in the Working Paper Series aim to disseminate interim results on agroforestry research and practices and stimulate feedback from the scientific community. Other publication series from the World Agroforestry Centre include: agroforestry perspectives, technical manuals and occasional papers.

Published by the World Agroforestry Centre

ICRAF Southeast Asia Regional Office

JL. CIFOR, Situ Gede, Sindang Barang, Bogor 16680

PO Box 161, Bogor 16001, Indonesia

Tel: +62 2518625415

Fax: +62 2518625416

Email: icraf-indonesia@cgiar.org

ICRAF Southeast Asia website: www.worldagroforestry.org/sea

(C) World Agroforestry Centre 2016

Working Paper 227

\section{Photos: World Agroforestry Centre}

The views expressed in this publication are those of the author(s) and not necessarily those of the World Agroforestry Centre.

Articles appearing in this publication may be quoted or reproduced without charge, provided the source is acknowledged.

All images remain the sole property of their source and may not be used for any purpose without written permission of the source. 


\section{Tentang Penulis}

Iwan Tri Cahyo Wibisono, menyelesaikan studi di Fakultas Kehutanan Institut Pertanian Bogor pada tahun 1999, penulis berkesempatan mempraktekkan ilmu yang diperolehnya secara langsung di beberapa program di lapangan. Sejak tahun 2001, penulis fokus di bidang rehabilitasi lahan basah bersama dengan Wetlands International Indonesia (WII). Selama 15 tahun terakhir, penulis terlibat sebagai perencana, pelaksana dan advisor/tenaga ahli dalam berbagai kegiatan rehabilitasi mangrove di Indonesia (Jawa, Sumatra, Nusa Tenggara Timur), Brunei Darussalam, Filipina, Thailand, dan Maldives. Pengalaman di berbagai kegiatan telah dituliskan dalam beberapa publikasi diantaranya Panduan Praktis rehabilitasi Pantai (WII-UNEP, 2006) dan Rehabilitasi pantai bebasis masyarakat; sebagai upaya pengurangan resiko bencana (WII-PMI, 2015). Saat ini penulis masih melanjutkan aktifitasnya di bidang rehabilitasi lahan basah (mangrove, gambut) dan menekuni MRV-REDD+. 


\section{Ringkasan}

Rehabilitasi pesisir dalam jangka panjang mampu meningkatkan fungsi dan manfaat sumber daya alam pesisir bagi masyarakat. ICRAF melakukan kajian dan penilaian kelayakan sebagai persiapan rehabilitasi pesisir di cluster yang terdiri dari Desa Taat, Matinan, dan Lokodidi, Kabupaten Buol, Sulawesi Tengah. Uji kelayakan menggunakan system Strength, Weakness, Opportunities, and Threats berdasarkan wawancara dan data lapangan mengenai kondisi dan sejarah lingkungan, serta kapasitas teknis dan kemauan masyarakat, pemerintah, dan pihak terkait. Uji kelayakan menilai bahwa rehabilitasi mangrove layak dilakukan di Desa Taat dan Lokodidi, sedangkan Desa Matinan layak untuk pengayaan mangrove. Untuk tiap desa diberikan rekomendasi desain teknis rehabilitasi yang antara lain berupa cara, lokasi, dan jenis tanaman untuk penanaman rehabilitasi. Sedangkan rekomendasi umum pengelolaan kegiatan berupa cara pendekatan kegiatan, tahapan dan tata waktu, dan teknik pembibitan dan penanaman mangrove. Kajian kelayakan dan rekomendasi dalam makalah ini diharapkan dapat menjadi panduan pelaksanaan rehabilitasi pesisir di ketiga desa tersebut agar rehabilitasi dapat berjalan lebih terarah dan terkelola dengan baik sehingga mencapai keberhasilan.

Kata Kunci Rehabilitasi pesisir, mangrove, kajian kelayakan, rekomendasi teknis, Kabupaten Buol 


\section{Ucapan Terima Kasih}

Working paper ini merupakan bagian dari proyek penelitian aksi Climate-smart, Tree-based, Coinvestment in Adaptation and Mitigation in Asia (Smart Tree-Invest) di Kabupaten Buol, Indonesia, dengan pendanaan dari International Fund for Agricultural Development (IFAD).

Review dan editing akhir working paper ini dilakukan oleh Tim Smart Tree-Invest Indonesia: Sacha Amaruzaman, Betha Lusiana, dan Sidiq Pambudi dari the World Agorofrestry Centre (ICRAF) Indonesia, dengan bantuan Gaia Khairina. 


\section{Daftar isi}

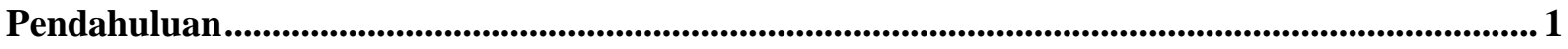

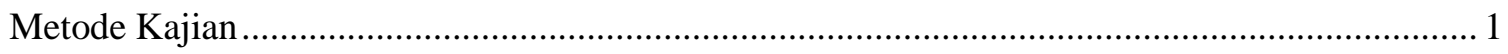

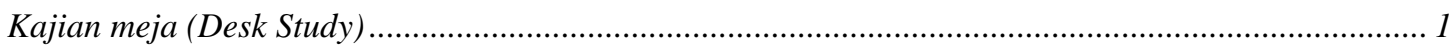

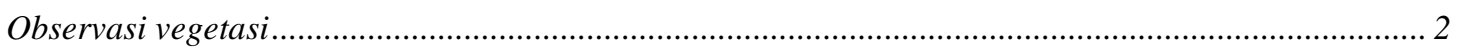

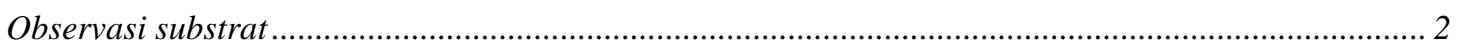

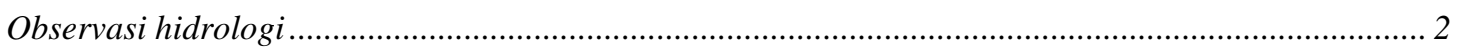

Status dan peruntukan lahan ............................................................................................... 2

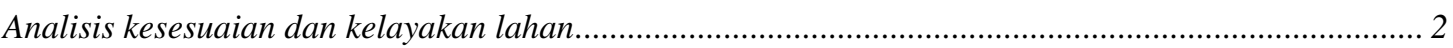

Hasil Kajian dan Temuan Lapangan ................................................................................................................... 3

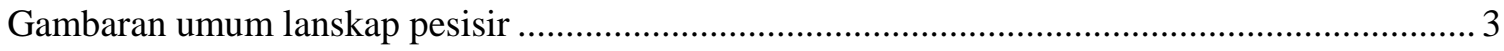

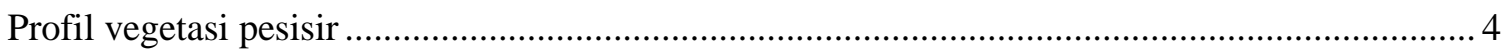

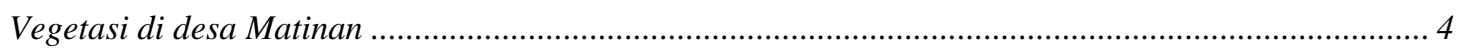

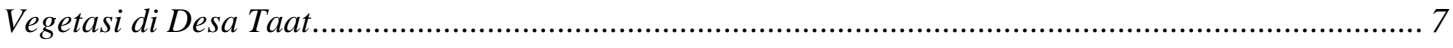

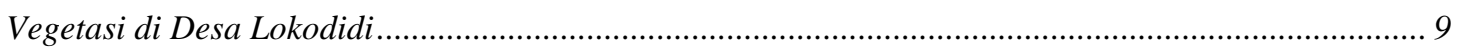

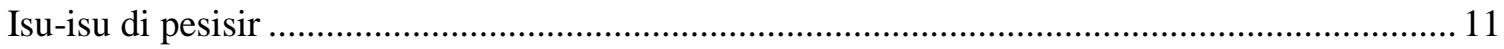

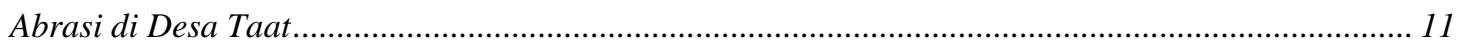

Penambangan emas di hulu sungai Desa Matinan......................................................................... 11

Penambangan pasir di pantai Desa Matinan ………………....................................................... 11

Pengumpulan biji emas di pantai Desa Matinan........................................................................... 12

Pembangunan jalan di Desa Lokodidi .................................................................................... 12

Persepsi masyarakat mengenai mangrove dan rehabilitasi ........................................................ 13

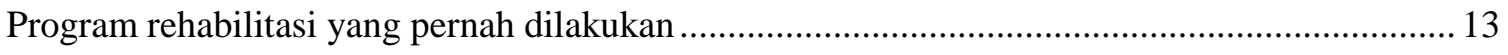

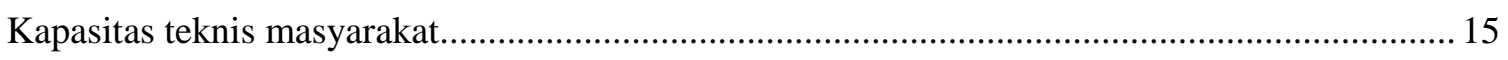

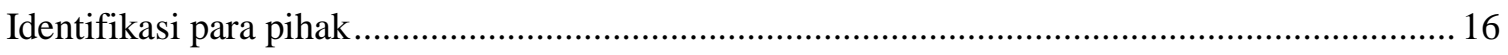

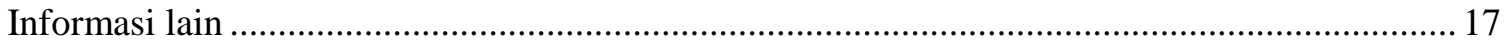

Analisis Kelayakan dan Rekomendasi Teknis Rehabilitasi Pesisir ...................................................... 18

Hasil analisis dan rekomendasi desain teknis untuk Desa Taat ................................................. 18

Analisis kelayakan rehabilitasi............................................................................................. 18

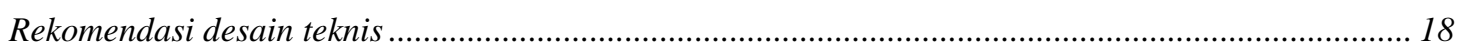

Hasil analisis dan rekomendasi desain teknis untuk Desa Lokodidi ............................................. 24

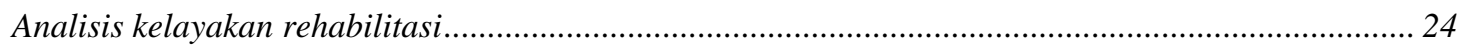

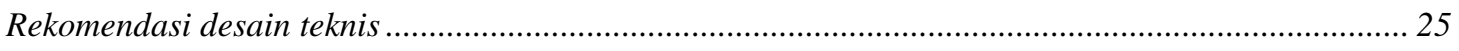

Hasil analisis dan rekomendasi desain teknis untuk Desa Matinan ............................................. 28

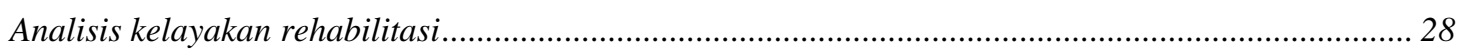

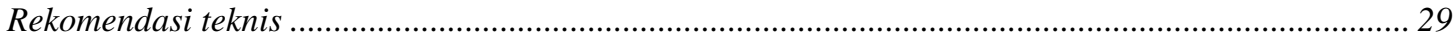

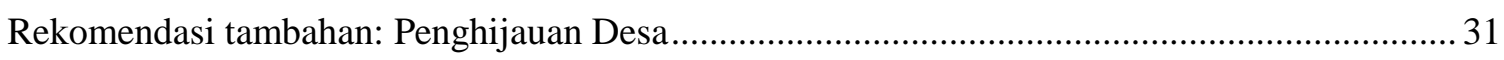

Rekomendasi Teknis Pengelolaan Kegiatan...............................................................................31 


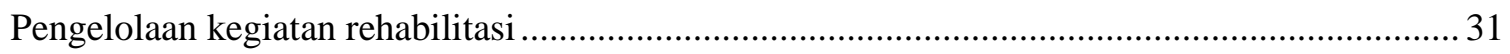

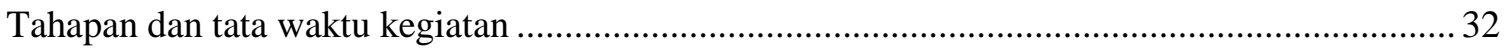

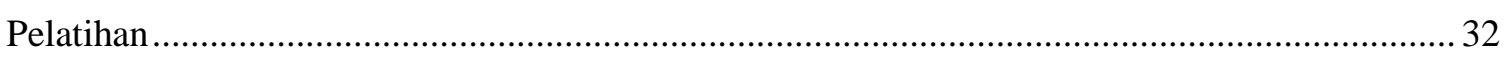

Pembibitan mangrove

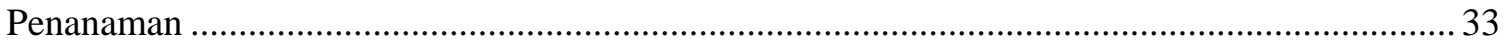

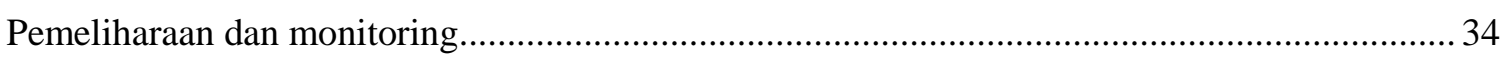

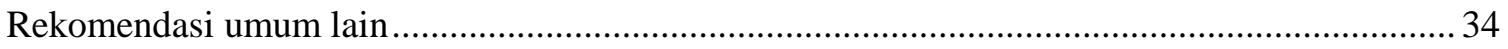

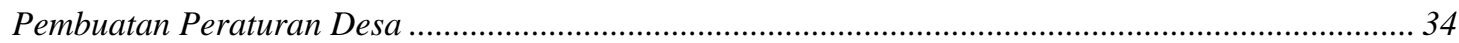

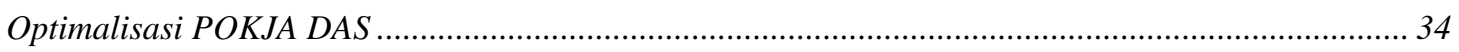

Pencegahan konversi mangrove dari dampak pembangunan jalan (Kasus desa Lokodidi).................... 34

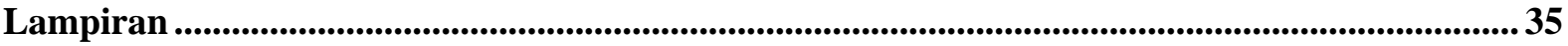

\section{Daftar Tabel}

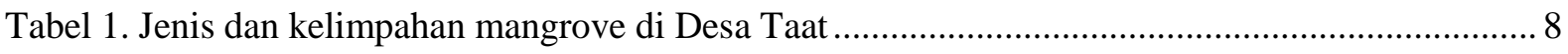

Tabel 2. Jenis dan kelimpahan mangrove di desa Lokodidi ................................................................. 10

Tabel 3. Jenis-jenis mangrove yang potensial untuk ditanam di Desa Taat ........................................ 22

Tabel 4. Jenis-jenis mangrove yang potensial untuk ditanam di Desa Lokodidi .................................. 26

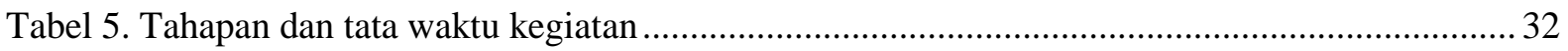

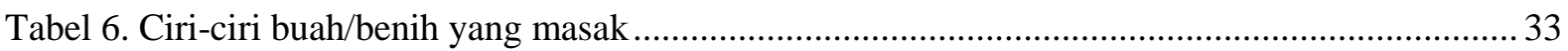

\section{Daftar Gambar}

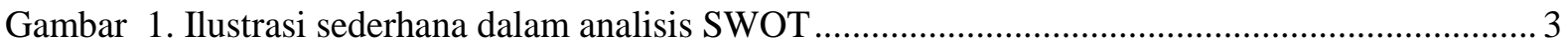

Gambar 2. Lanskap pesisir yang mencakup tiga desa; Lokodidi, Matinan, dan Taat............................ 3

Gambar 3. Sebaran mangrove di Desa Matinan (poligon bergaris putih) .......................................... 5

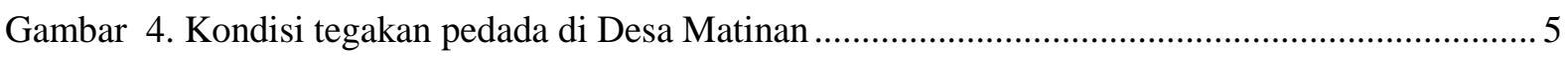

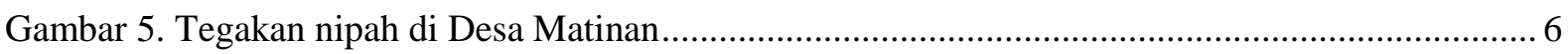

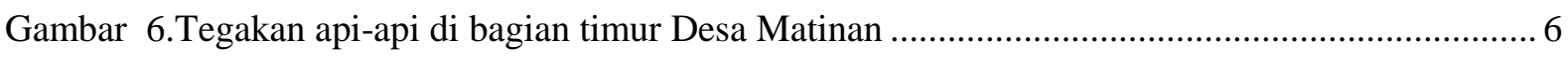

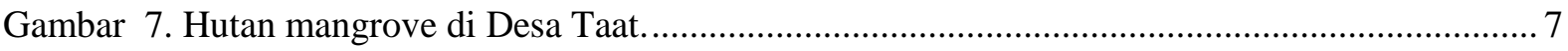

Gambar 8. Jenis-jenis mangrove di Desa Taat yang berhasil didokumentasikan .................................. 8

Gambar 9.Sebaran hutan magrove di Desa Lokodidi ............................................................................ 9

Gambar 10. Jenis-jenis mangrove di Desa Taat yang berhasil didokumentasikan. ............................. 10

Gambar 12. Penambangan pasir oleh masyarakat................................................................................ 12 
Gambar 13.Alat yang digunakan masyarakat untuk mencari emas

Gambar 14. Potensi dampak proyek pembangunan jalan terhadap hutan mangrove di Desa Lokodidi

Gambar 15. Pelaksanaan program KBR tahun 2010/11 (dokumentasi pribadi Ketua Kelompok Kuda Laut/Bp. Kades Desa Taat terpilih)

Gambar 16. Tanaman mangrove yang mati (kiri), pagar yang telah rusak (kanan) dalam kegiatan rehabilitasi mangrove 2014 (KBR)

Gambar 17. Hasil pemetaan pihak dalam konteks rehabilitasi pesisir

Gambar 18. Hasil analisis SWOT dalam penilaian prospek rehabilitasi di Desa Taat ........................ 18

Gambar 19. Ilustrasi sederhana pemagaran koloni tanaman mangrove .............................................. 19

Gambar 20. Ilustrasi sederhana penempatan koloni tanaman mangrove di lokasi penanaman ........... 20

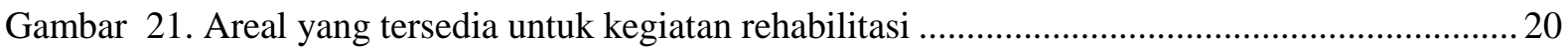

Gambar 22. Lokasi yang direkomendasikan untuk rehabilitasi mangrove di Desa Taat..................... 22

Gambar 23. Contoh penerapan Hybrid Engineering (HE) di Demak-Jawa Tengah (foto: Wetlands International)

Gambar 24. Lokasi yang direkomendasikan untuk penerapan Hybrid Engineering........................... 24

Gambar 25. Hasil analisis SWOT dalam penilaian prospek rehabilitasi di Desa Lokodidi.................. 25

Gambar 26. Lokasi yang direkomendasikan untuk rehabilitasi mangrove di Desa Lokodidi ............. 26

Gambar 27. Tambak terlantar yang miliki potensi untuk dijadikan demosite silvofishery .................. 27

Gambar 28. Penanaman mangrove di sepanjang pematang tambak ..................................................28

Gambar 29. Penanaman mangrove di sepanjang tambak, dikombinasikan dengan sistem jalur ......... 28

Gambar 30. Hasil analisis SWOT dalam penilaian prospek rehabilitasi di Desa Matinan .................. 29

Gambar 31. Ilustrasi sederhana usulan teknis pengkayaan di tegakan nipah....................................... 30

Gambar 32. Ilustrasi sederhana teknis pengkayaan di tegakan api-api ............................................. 30 


\section{Pendahuluan}

Rehabilitasi merupakan salah satu opsi dalam meningkatkan daya dukung lingkungan pesisir, terutama pada areal yang telah mengalami kerusakan. Dalam jangka panjang, rehabilitasi pesisir diharapkan mampu meningkatkan fungsi dan manfaat sumberdaya alam pesisir bagi masyarakat.

Sejak tahun 90-an, pemerintah Indonesia telah melakukan berbagai program rehabilitasi berskala besar, termasuk Gerakan Rehablitasi Hutan dan Lahan (GRNHL) dan Kebun Bibit Rakyat (KBR). Kegiatan ini telah menjangkau hampir di seluruh wilayah Indonesia, termasuk di kawasan pesisir Provinsi Sulawesi Tengah. Namun sayang, kegiatan berskala besar ini masih belum dapat terkelola dengan baik sehingga tingkat keberhasilannya rendah. Berbagai kajian mengidentifikasi beberapa faktor yang berkontribusi terhadap rendahnya keberhasilan program ini, mulai dari perencanaan hingga pelaksanaan. Di lapangan, banyak sekali ditemukan kasus dimana penanaman mangrove di lakukan di lokasi yang salah, penanaman dilakukan secara sembarangan, atau menanam bibit yang masih belum siap untuk ditanam. Berkaca dari hal ini maka kegiatan rehabilitasi pesisir harus dirancang dengan tepat sesuai dengan kondisi tapak, diimplementaskan di lapangan dengan tata cara atau prosedur yang benar, serta dilakukan pemeliharaan yang berkelanjutan.

Di dalam program "Climate-smart, Tree-based, Co-investment in Adaptation and mitigation in Asia (Smart Tree-Invest)" The World Agroforestry Centre (ICRAF) bekerja di daerah pesisir Kabupaten Buol yang terdiri dari Desa Taat, Matinan, dan Lokodidi. Di ketiga desa yang terletak di Kecamatan Gadung ini, program mendorong upaya-upaya untuk meningkatkan kualitas dan daya dukung pesisir, salah satunya melalui kegiatan rehabilitasi pesisir.

Sebagai bagian dari persiapan, ICRAF secara khusus melakukan suatu kajian untuk menilai kelayakan kegiatan rehabilitasi di ketiga desa target. Kegiatan kajian ini juga mencakup rekomendasi desain teknis rehabilitasi pesisir sebagai panduan pelaksanaan kegiatan di ketiga desa tersebut. Dengan dokumen ini, pelaksanaan kegiatan diharapkan dapat berjalan lebih terarah dan terkelola dengan baik sehingga mencapai keberhasilan.

Kajian ini memiliki beberapa tujuan sebagai berikut:

- Mengidentifikasi karakteristik lanskap dan kondisi biofisik di wilayah kajian.

- Mengeksplorasi berbagai informasi dan data yang terkait dengan manajemen pesisir dan kegiatan rehabilitasi di wilayah kajian.

- Menganalisis kelayakan kegiatan rehabilitasi pesisir di Desa Taat, Matinan, dan Lokodidi.

- Mengembangkan desain teknis rehabilitasi pesisir sebagai panduan untuk pelaksanaan kegiatan di Desa Taat, Matinan, dan Lokodidi.

\section{Metode Kajian}

\section{Kajian meja (Desk Study)}

Kajian ini dilakukan di Bogor dengan tujuan utama memperoleh gambaran atau kondisi umum ketiga desa dan mengidentifikasi beberapa isu-isu kunci. Selain mempelajari profil proyek Smart Tree- 
Invest, dilakukan pula pengumpulan berbagai informasi yang terkait dengan sumberdaya pesisir di ketiga desa dari berbagai sumber.

Kajian ini juga mengumpulkan beberapa citra satelit dan peta-peta untuk melakukan analisa awal kondisi lansekap dan ekosistem. Hasil analisis ini digunakan untuk menentukan prioritas lokasi-lokasi yang akan dikunjungi.

\section{Observasi vegetasi}

Kegiatan ini dilakukan untuk mengetahui profil umum vegetasi di ketiga desa, baik tumbuhan kayu maupun non kayu. Untuk memperoleh profil vegetasi yang mewakili wilayah kajian secara utuh, observasi dilakukan pada tipe-tipe tutupan yang dijumpai di lapangan. Hasil akhir dari observasi vegetasi berupa daftar jenis, tutupan lahan, dan penyebarannya. Karena merupakan hasil observasi maka kelimpahan tanaman ini digambarkan secara kualitatif.

Vegetasi di wilayah kajian pada umumnya merupakan jenis-jenis umum pesisir dimana sebagian besar telah dikenal. Untuk jenis yang belum dapat teridentifikasi di lapangan, dilakukan pengambilan spesimen untuk diidentifikasi di Bogor.

\section{Observasi substrat}

Kegiatan ini mengacu pada pengamatan sifat fisik tanah di wilayah kajian, terutama pada lokasilokasi yang memiliki potensi untuk kegiatan rehabilitasi. Parameter kunci yang digunakan dalam observasi ini adalah jenis tekstur tanah yang meliputi: lumpur, lumpur berpasir, pasir, pasir berlumpur, liat dan lain-lain.

\section{Observasi hidrologi}

Pengamatan ini menitikberatkan pada kondisi perairan di areal yang memiliki potensi untuk rehabilitasi. Beberapa parameter kunci dalam observasi ini adalah pola pasang surut air laut, sirkulasi dan dinamika air, dan kekuatan ombak. Sebagai pelengkap informasi, dilakukan wawancara dengan masyarakat yang benar-benar mengerti karakteristik perairan di ketiga desa.

\section{Status dan peruntukan lahan}

Kegiatan ini secara khusus mengidentifikasi kepemilikan lahan serta peruntukannya saat ini dan di masa mendatang. Hal ini sangat penting mengingat kegiatan rehabilitasi membutuhkan jaminan jangka panjang agar tidak dikonversi dikemudian hari. Kegiatan ini dilakukan melalui wawancara dengan nara sumber yang mengetahui status kepemilikan dan peruntukannya.

\section{Analisis kesesuaian dan kelayakan lahan}

Data dan informasi yang telah dikumpulkan di lapangan dianalisa lebih lanjut untuk menilai kesesuaian lahan untuk keperluan rehabilitasi. Penilaian ini mutlak dilakukan untuk menentukan lokasi mana yang sesuai dan lokasi mana yang tidak sesuai untuk ditanami. Kondisi tanah (substrat) dan hidrologi merupakan dua aspek utama yang harus mendapatkan perhatian khusus.

Tidak semua lokasi yang sesuai (suitable) selalu layak (feasible) untuk kegiatan rehabilitasi. Untuk itu, lokasi yang suitable harus di analisis lebih lanjut dengan mempertimbangkan beberapa aspek yang ada di lapangan antara lain: aksesibilitas, persepsi masyarakat tentang rehabilitasi, kemauan masyarakat, kapasitas teknis masyarakat, status lahan, peruntukan lahan kedepan, dan lain-lain. 
Penilaian kelayakan (feasibility) dilakukan dengan mengunakan analisis SWOT. Analisis SWOT secara sederhana mengkategorikan berbagai informasi dan data kedalam Strengths (Kekuatan), Weakness (Kelemahan), Opportunities (peluang), dan Threats (Ancaman) (gambar 1). Apabila suatu lokasi memiliki banyak kekuatan dan peluang, sementara hambatan dan ancamannya sedikit, maka lokasi ini dinyatakan layak. Dan sebaliknya, bila terlalu banyak ancaman dan hambatan, sementara kekuatan dan peluangnya sangat terbatas, maka lokasi ini "mungkin" tidak feasible (walaupun secara biofisik lokasinya sesuai atau suitable).

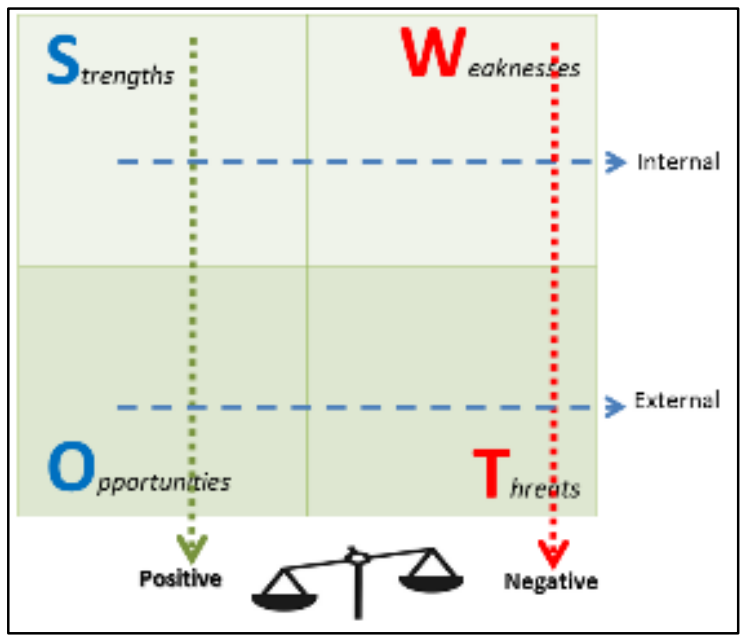

Gambar 1. Ilustrasi sederhana dalam analisis SWOT

\section{Hasil Kajian dan Temuan Lapangan}

\section{Gambaran umum lanskap pesisir}

Desa Matinan, Desa Taat dan Lokodidi berada dalam satu lansekap pesisir utara Kecamatan Gadung. Total garis pantai ketiga desa diperkirakan sepanjang $7.39 \mathrm{~km}$ dengan perincian Desa Matinan 1.15 km, Desa Taat 2.07 km dan Desa Lokodidi 4.17km (gambar 2).

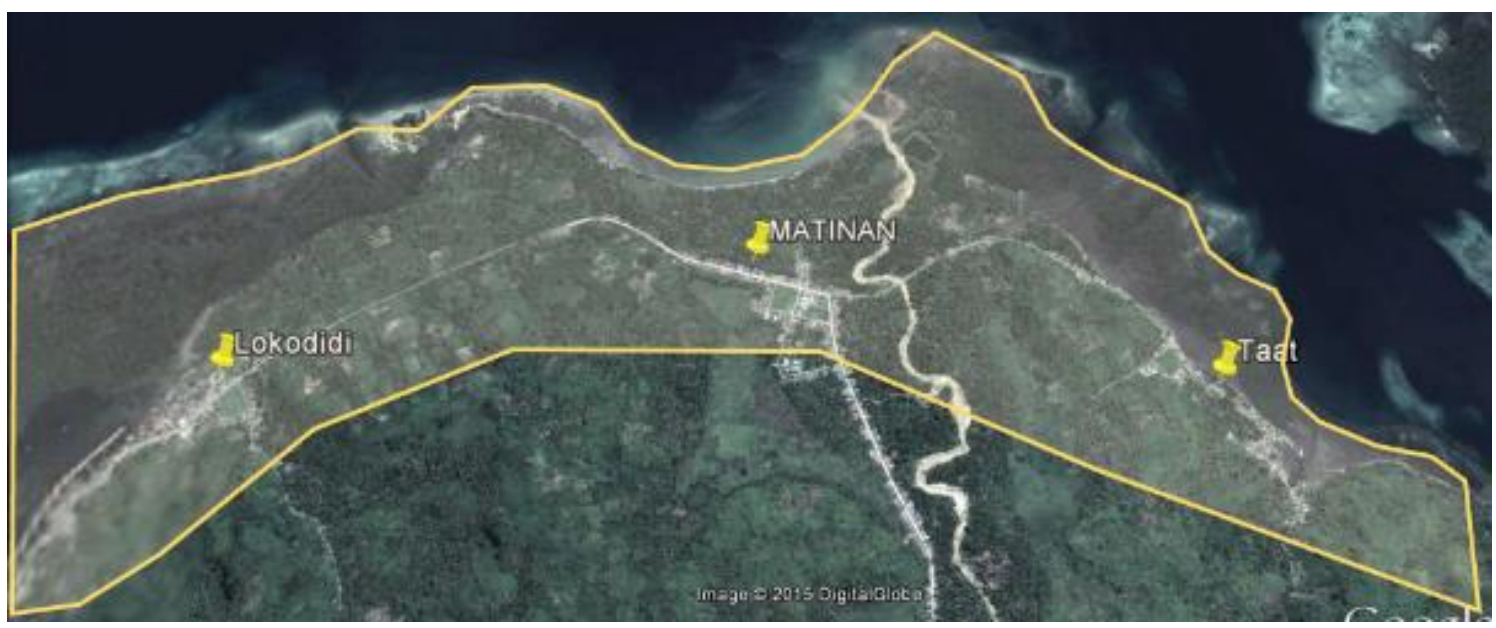

Gambar 2. Lanskap pesisir yang mencakup tiga desa; Lokodidi, Matinan, dan Taat 
Pantai di Desa Taat dan Lokodidi memiliki karakteristik yang cukup mirip dimana sebagian besar pantai memiliki substrat lumpur. Namun bila dilihat lebih dekat, pantai berlumpur di Desa Lokodidi jauh lebih luas dan tebal dibandingkan dengan yang ada di Desa Taat. Kantung-kantung areal berlumpur di Desa Lokodisi tersebar hampir merata disepanjang pantai desa. Kondisi inilah yang menjadi alasan mengapa mangrove di desa Lokodidi lebih luas dan tersebar merata di pesisir desa. Di Desa Taat, substrat lumpur lebih terkonsentrasi di zona depan pantai yang saat ini ditumbuhi oleh mangrove. Diantara zona areal berlumpur (di zona depan) dan garis pantai, terbentang hamparan lumpur berpasir dan pasir berbatu (karang). Hamparan lumpur berpasir ditumbuhi oleh mangrove (terutama Bruguiera gymnorrhiza dan Ceriops tagal) yang tersebar dengan kerapatan yang jarang, bahkan sebagian diantaranya soliter. Sementara itu, hamparan pasir berbatu merupakan lahan kosong, tidak ditumbuhi oleh vegetasi. Sebagaimana terlihat pada gambar 2 diatas, terlihat bahwa kawasan pemukiman desa Taat dan Lokodidi berada di sepanjang garis pantai namun cukup terlindungi oleh hutan mangrove yang berada di zona depan.

Berbeda dengan dua desa di atas, pesisir Desa Matinan memiliki karakteristik pantai berpasir. Substrat berlumpur hanya dijumpai di muara sungai yang berada di bagian timur desa. Karena karakteristik ini maka kondisi vegetasi di pantai Desa Matinan didominasi oleh tanaman daratan (inland vegetation). Di belakang garis pantai, terdapat hamparan tanah mineral yang relatif terbebas dari dari pengaruh air laut. Karena inilah, masyarakat Desa Matinan mengembangkan kebun kelapa di sepanjang pantai Desa Matinan. Sejumlah kecil tegakan mangrove hanya terdapat di muara sungai yang bersubtsrat lumpur, areal di kanan-kiri sungai kecil, dan zona depan di ujung barat desa. Berbeda dengan dua desa tetangga, kawasan pemukiman desa Matinan berada di belakang kebun kelapa dengan jarak terdekat 250 meter dari garis pantai.

\section{Profil vegetasi pesisir}

Profil vegetasi yang ada di ketiga desa sangat dipengaruhi oleh karakteristik lansekap sebagaimana dijelaskan di atas. Hutan mangrove memiliki kecenderungun untuk tumbuh di pantai berlumpur, sementara vegetasi pantai daratan (terestrial coastal vegetation) cenderung mengokupasi pesisir yang pantainya berpasir. Paragraf di bawah ini merupakan gambaran umum profil vegetasi di tiga desa berdasarkan hasil observasi lapangan.

\section{Vegetasi di desa Matinan}

Secara umum, tipe vegetasi di Desa Matinan dapat dikelompokkan menjadi tujuh yaitu 1) Kebun kelapa, 2) semak belukar, 3) mangrove,4) vegetasi di pemukiman, 5) kebun campuran, 6) Pantai berpasir, dan 7) rawa.

Kebun kelapa menempati peringkat teratas dalam hal luas dan kelimpahannya. Sesuai dengan namanya, kebun kelapa didominasi oleh pohon kelapa (Cocos nucifera). Sebagian besar pohon kelapa yang dibudidayakan merupakan jenis kelapa darat, dan sebagian kecil adalah "kelapa solo" yang merupakan jenis hibrida. Di depan kebun kelapa, dijumpai hamparan pantai berpasir yang kondisi penutupannya relatif terbuka. Galaran (Ipomea-pes ceprae) merupakan jenis tumbuhan yang paling umum dijumpai di pantai berpasir. Semak belukar dapat dijumpai di sela-sela dominasi kebun kelapa dan areal lain yang belum dibudidayakan oleh masyarakat. Vegetasi yang ditemukan di semak belukar terdiri dari jenis rumput, herba, semak, hingga pohon. Di wilayah pemukiman, vegetasi yang dijumpai 
merupakan jenis yang sengaja ditanam penduduk. Pada umumnya jenis-jenis yang ditanam ini merupakan jenis serbaguna (MPTS-Multi Purpose Tree Species), memiliki nilai estetika, atau tanaman peneduh. Sebagian besar masyarakat di Desa Matinan memiliki kebun campuran yang ditanami beberapa jenis komoditas kebun. Pada dataran yang rendah dan terhubung dengan sungai atau alur air, terdapat rawa yang ditumbuhi beberapa jenis tumbuhan rawa termasuk Sagu (Metroxylon sagu).

Luas mangrove di Desa Matinan sangat kecil, diperkirakan hanya 0.3 ha. Mangrove seluas ini tersebar di tiga lokasi yaitu tegakan Pedada (A) di sebelah barat, tegakan nipah (B) di sekitar muara sungai bagian barat desa, dan tegakan api-api (C) di muara sungai timur desa (gambar 3).

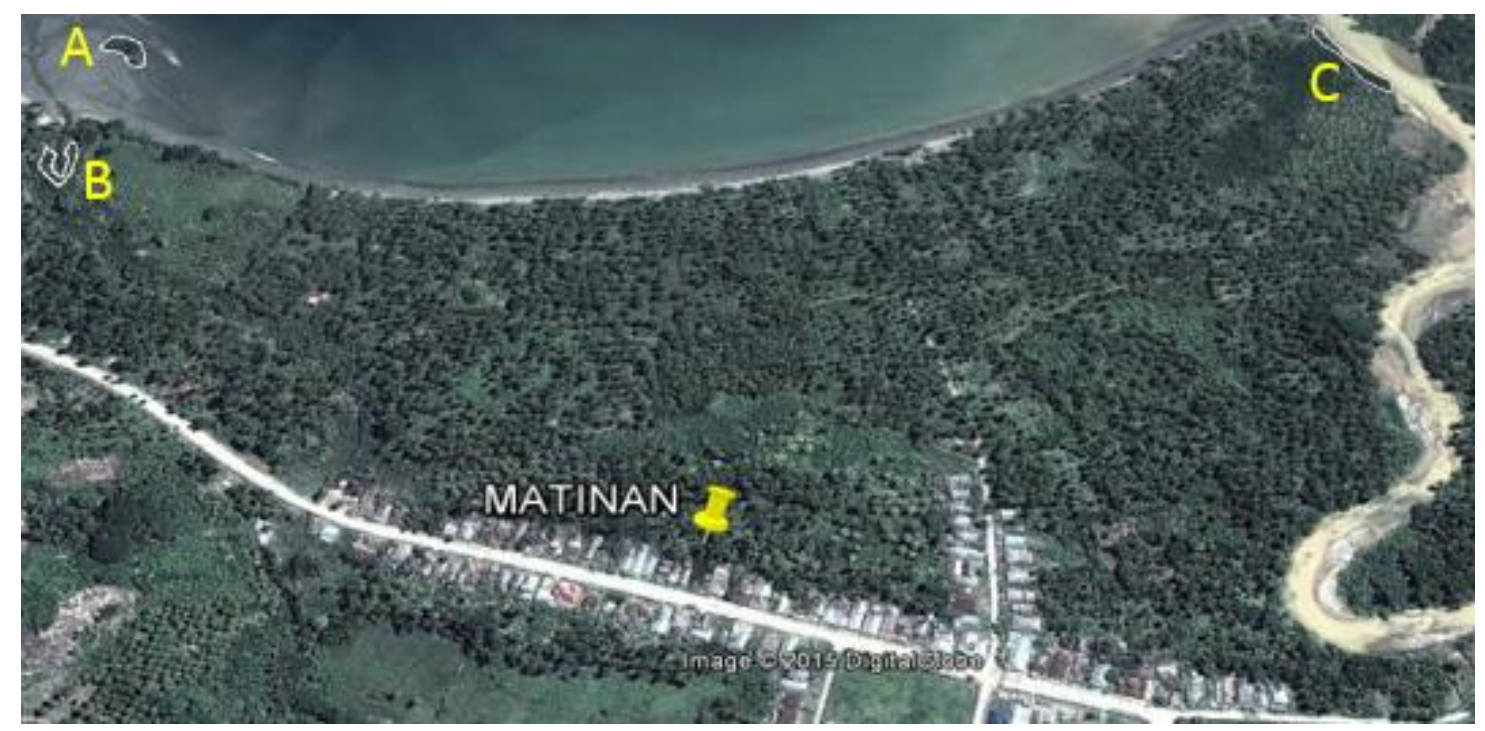

Gambar 3. Sebaran mangrove di Desa Matinan (poligon bergaris putih)

Luas tegakan pedada diperkirakan kurang dari 0.1 ha, terdiri dari empat pohon pedada (Sonneratia alba) yang telah berumur tua. (gambar 4). Saat kunjungan dilakukan, tegakan ini mengalami kendala regerenasi sebagai akibat sedimentasi pasir dan hempasan gelombang laut. Apabila keempat pohon ini mati, maka tegakan pedada ini benar-benar akan punah dari Desa Matinan.

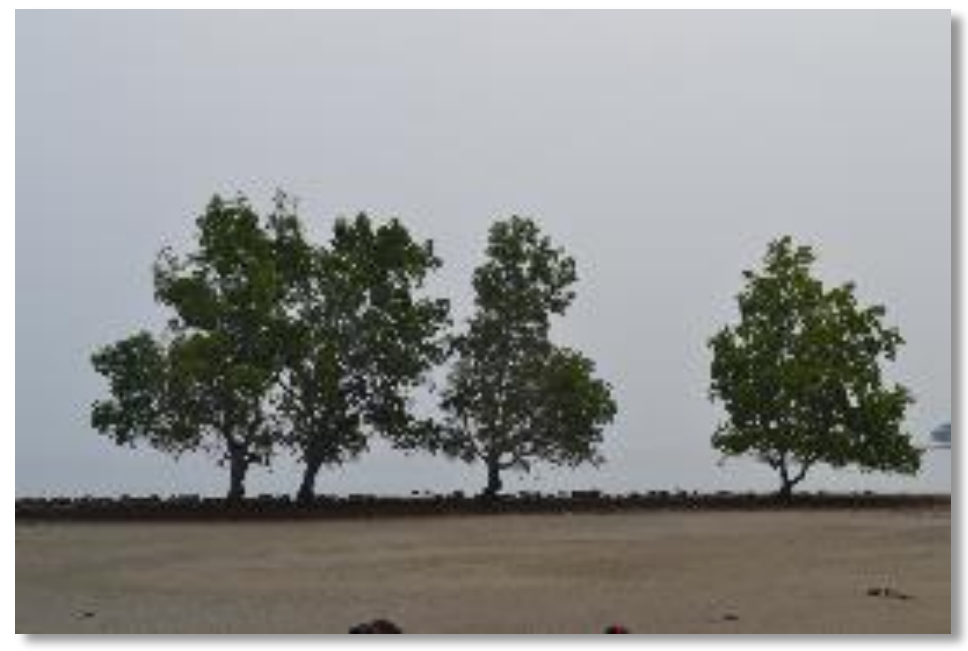

Gambar 4. Kondisi tegakan pedada di Desa Matinan 
Tegakan nipah berada di belakang muara sungai sebelah barat desa, saat kunjungan dilakukan muaranya tertutup oleh pasir. Berdasarkan informasi dari masyarakat, muara ini hanya tertutup di musim timur saja. Di musim barat, sedimen yang menutup muara akan hilang dengan sendirinya, dan sungai akan terhubung kembali dengan lautan. Tegakan ini diperkirakan kurang dari $0.1 \mathrm{Ha}$, didominasi oleh Nipah (Nypa fruticans) (gambar 5). Hanya ada sedikit jenis mangrove lainnya diselasela dominasi nipah yaitu Api-api (Avicennia marina), (Bruguiera gymnorrhiza), dan Ceriops tagal.

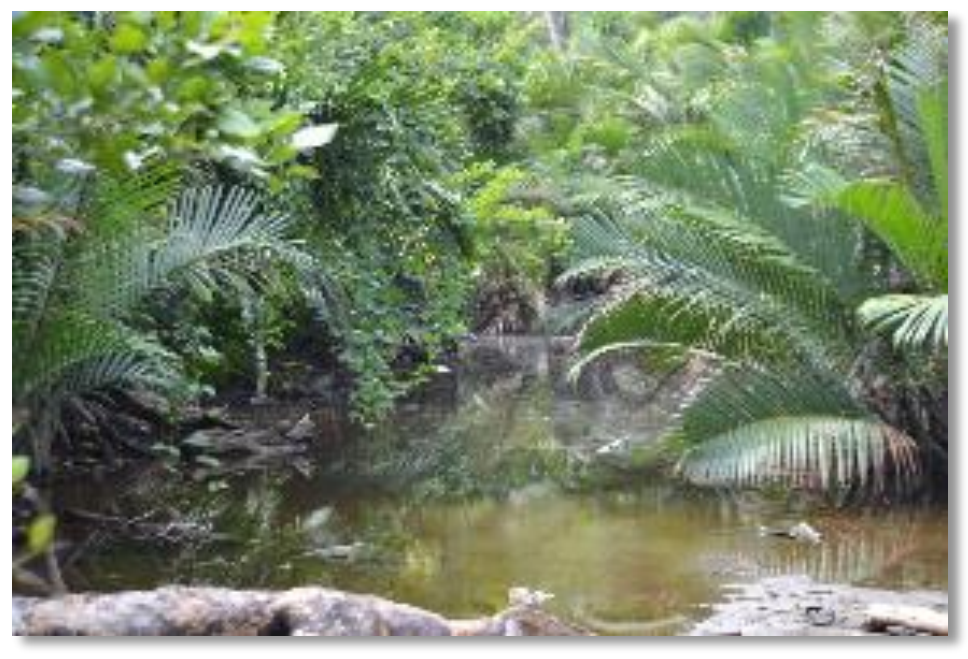

Gambar 5. Tegakan nipah di Desa Matinan

Tegakan mangrove lainnya juga dijumpai di muara timur Desa Matinan, diperkirakan seluas 0.1 ha dan didominasi oleh Api-api (Avicennia marina) (gambar 6). Dominasi api-api pada tegakan ini diselingi oleh beberapa jenis mangrove lainnya yaitu Nypa fruticans, Bruguiera gymnorrhiza, Sonneratia alba dan Ceriops tagal dengan jumlah yang sangat terbatas. Di belakang tegakan ini terdapat hamparan rawa payau yang ditumbuhi oleh Acanthus ilicifoius dan Achrosticum aureum.

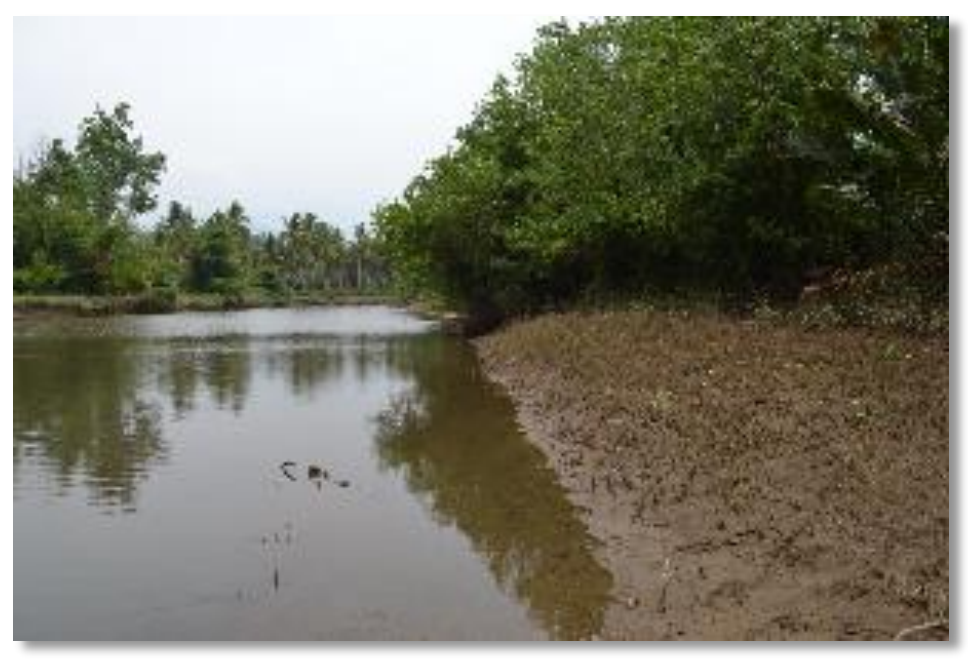

Gambar 6.Tegakan api-api di bagian timur Desa Matinan 
Hasil observasi yang dilakukan di Desa Matinan menghasilkan daftar jenis tumbuhan/tanaman yang dikelompokkan ke dalam tipe vegetasi di Desa Matinan, sebagaimana terangkum dalam lampiran 1.

\section{Vegetasi di Desa Taat}

Observasi yang dilakuan di Desa Taat setidaknya mengidentifikasi enam jenis tipe vegetasi yaitu 1) Mangrove, 2) vegetasi di wilayah pemukiman, 3) kebun campuran,4) semak belukar, 5) kebun kelapa, dan 6) rawa.

Berdasarkan analisis spasial, hutan mangrove di Desa Taat diperkirakan seluas 58.8 hektar. Hutan mangrove ini tidak tersambung secara penuh dalam suatu hamparan, melainkan terbagi kedalam sepuluh tegakan dengan luas masing-masing antara 0.1 ha - 42 hektar. Pemisah tegakan magrove di desa ini adalah beberapa alur air yang setiap harinya dilalui nelayan untuk melaut.

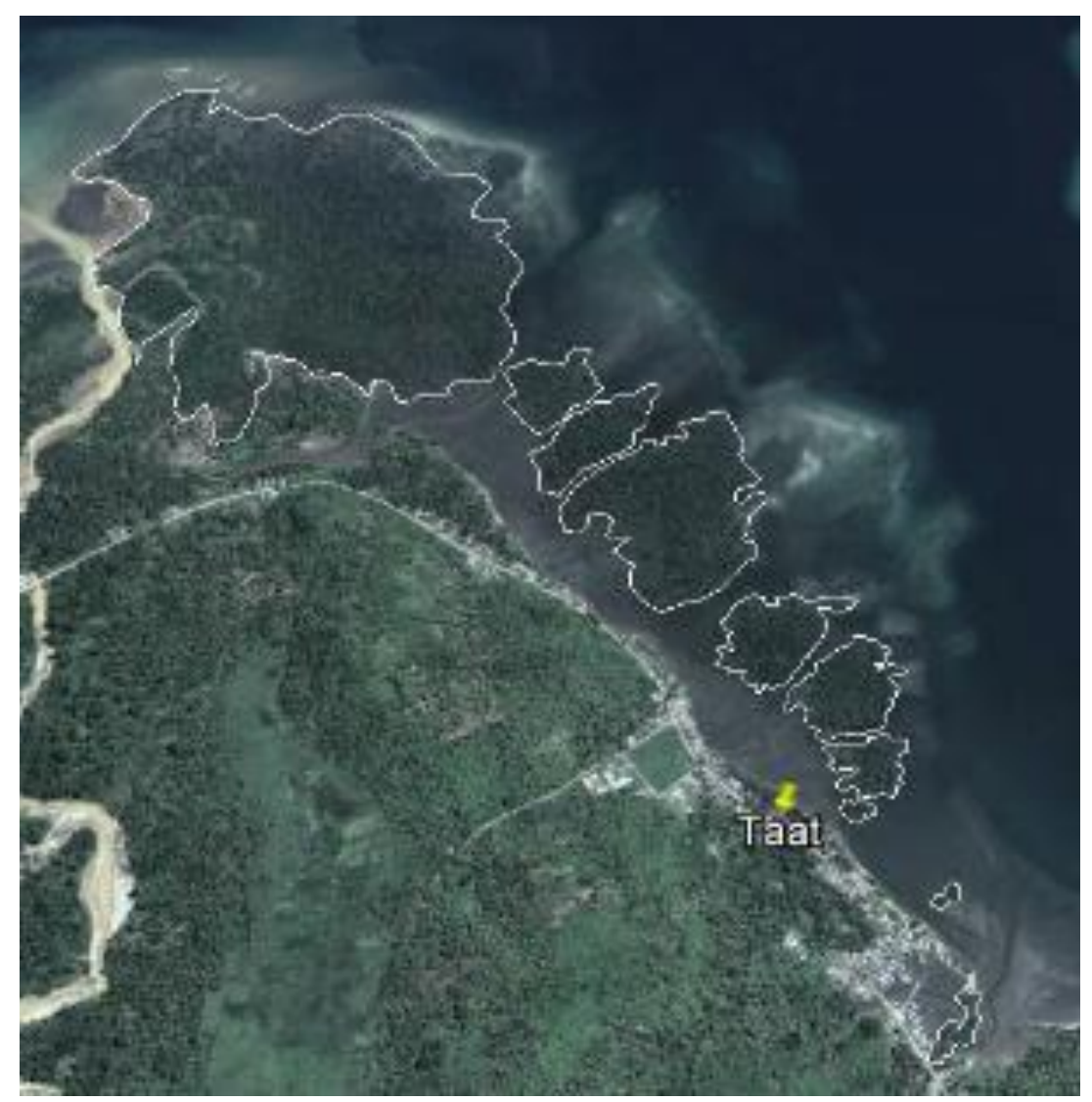

Gambar 7. Hutan mangrove di Desa Taat.

Observasi yang dilakukan di lapangan setidaknya mengidentifikasi 12 jenis mangrove. Beberapa jenis yang paling umum ditemukan adalah Cengal (Ceriops tagal), Pedada (Sonneratia sp.)., Bakau (Rhizophora sp.), dan Api-api (Avicennia marina). Beberapa jenis mangrove lainnya juga dijumpai yaitu Bruguiera gymnorrhiza, Xylocarpus granatum, Jeruju (Acanthus ilicifolius), dan Camptostemon spp. Di sekitar alur sungai, pohon Nipah (Nypa fruticans) sangat mudah dijumpai, kadang-kadang diselingi oleh Jeruju (Acanthus ilicifolius). Jenis dan kelimpahan mangrove di Desa Taat tersaji dalam tabel 2 di bawah ini. 
Tabel 1. Jenis dan kelimpahan mangrove di Desa Taat

\begin{tabular}{rlccc}
\hline No & Jenis & Nama Indonesia & Nama lokal & Kelimpahan \\
\hline 1 & Sonneratia alba & Pedada & Payapat & ++ \\
\hline 2 & Sonneratia caseolaris & Pedada & - & + \\
\hline 3 & Bruguiera gymnorrhiza & Tanjang merah & Tonggi & + \\
\hline 4 & Avicennia marina & Api-api & Peoapi & ++ \\
\hline 5 & Rhizophora apiculata & Bakau sedang & - & ++ \\
\hline 6 & Rhizophora mucronata & Bakau besar & - & + \\
\hline 7 & Nypa fruticans & Nipah & Kibuy & + \\
\hline 8 & Ceriops tagal & Tengar & Tanga & ++ \\
\hline 9 & Xylocarpus granatum & Nyiri & - & + \\
\hline 10 & Dolichandrone spathacea & - & Tuwele & + \\
\hline 11 & Acanthus ilicifolius & Jeruju & - & + \\
\hline 12 & Camptostemon sp. 1 & - & + \\
\hline
\end{tabular}
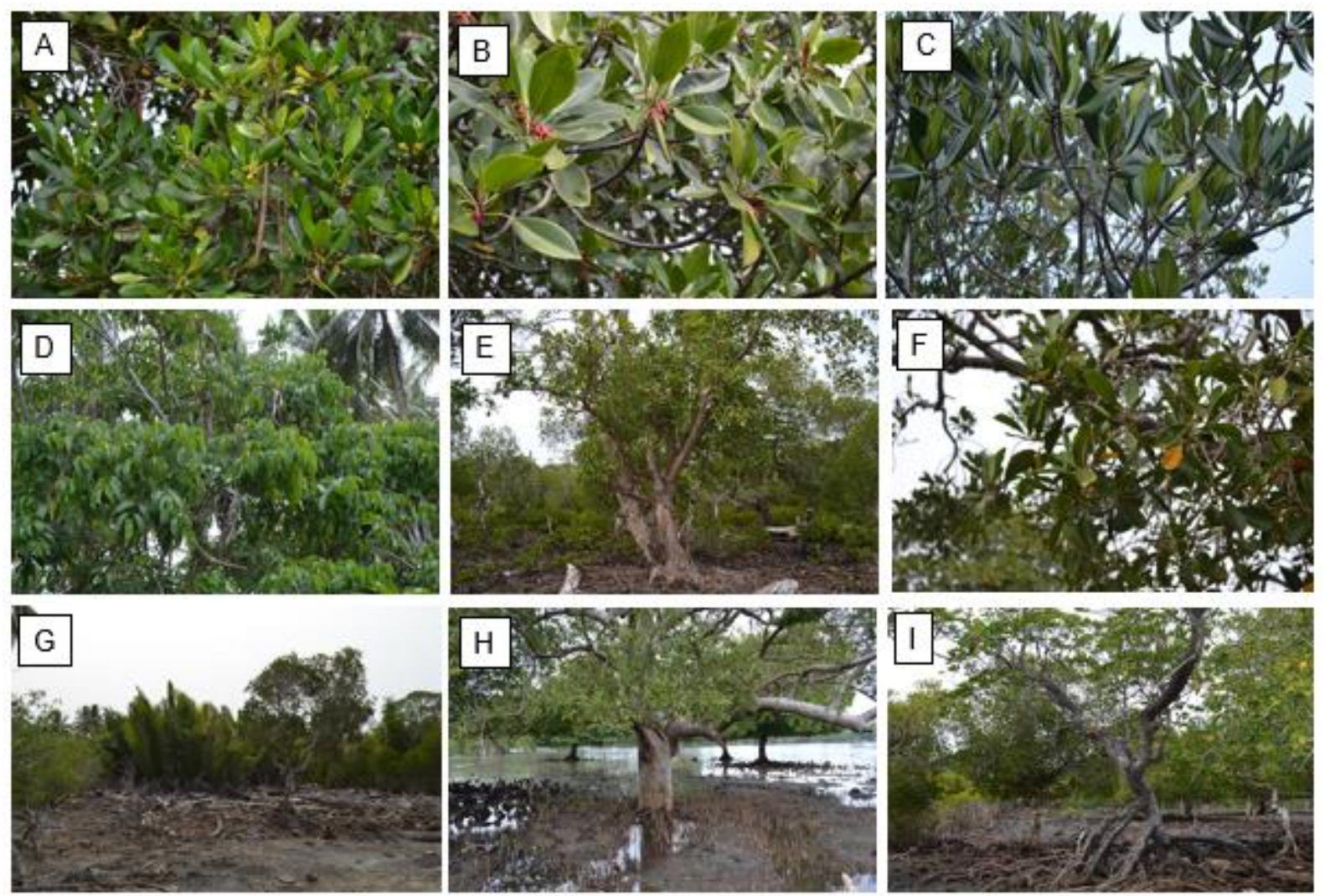

Gambar 8. Jenis-jenis mangrove di Desa Taat yang berhasil didokumentasikan: Ceriops tagal (A), Bruguiera gymnorrrhiza (B), Rhizophora apiculata (C), Dolichandrone spathacea (D), Xylocarpus granatum (E), Camptostemon sp.1 (F), Nypa fruticans (G), Avicennia marina (H), dan Rhizophora mucronata (I)

Masyarakat Desa Taat banyak yang memiliki kebun kelapa, sebagian besar kebun berada di daratan belakang mangrove dan dekat dengan pemukiman. Sementara di wilayah pemukiman sendiri, beberapa jenis tanaman sengaja ditanam oleh masyarakat. Kayu kuda (Lannea caromondalica) dan 
Gamal (Gliricidia sepium) seringkali ditanam sebagai tanaman pagar, ditanam dengan menggunakan stek batang dengan jarak tanam yang rapat. Sementara di pekarangan rumah, penduduk lebih cenderung menanam jenis tanaman buah-buahan dan bunga-bungaan. Di sepanjang jalan desa, dapat dijumpai kebun campuran milik masyarakat dimana didalamnya terdapat beberapa jenis tanaman antara lain pala, cengkeh, dan kopi. Sementara pada lahan yang belum dikembangkan masyarakat, pada umumnya berupa semak atau semak belukar. Sebagian besar semak dan semak belukar ini berada lereng bukit. Rawa yang ada di desa sebagian besar berada di belakang kawasan pemukiman, dimana Sagu (Metroxylon sagu) merupakan jenis tumbuhan yang paling umum dijumpai.

Hasil observasi yang dilakukan di Desa Taat menghasilkan daftar jenis tumbuhan/tanaman yang dikelompokkan ke dalam tipe vegetasi, sebagaimana terangkum dalam lampiran 1.

\section{Vegetasi di Desa Lokodidi}

Berdasakan observasi lapangan, Desa Lokodidi setidaknya memiliki enam jenis tipe vegetasi yaitu 1) Mangrove, 2) vegetasi di wilayah pemukiman, 3) kebun campuran,4) semak belukar, 5) kebun kelapa, dan 6) rawa.

Berdasarkan analisis spasial, hutan mangrove di Desa Lokodidi diperkirakan seluas 120.9 hektar. Areal seluas ini terdiri dari satu hamparan hutan seluas luasan 120 ha dan satu koloni mangrove kecil seluas 0.9 ha (gambar 9).

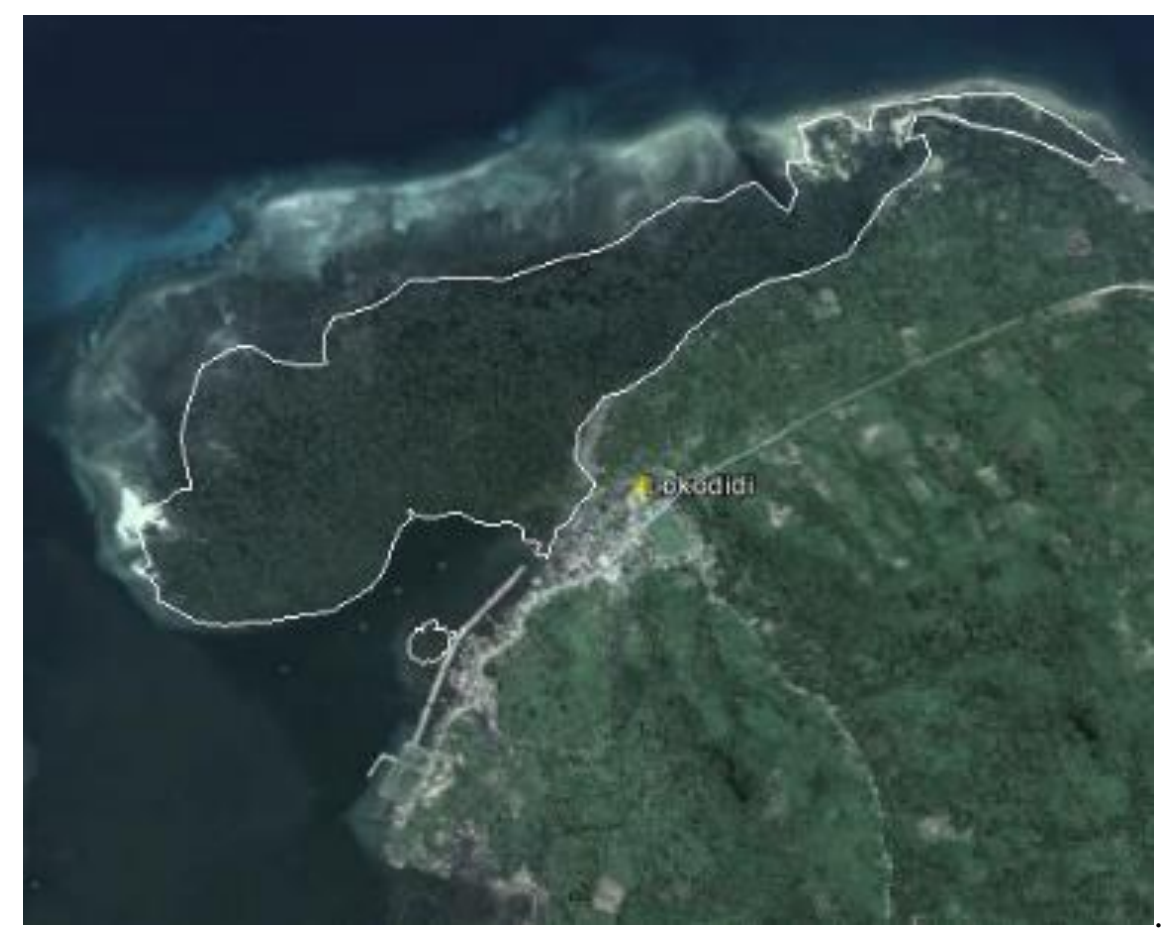

Gambar 9.Sebaran hutan magrove di Desa Lokodidi

Dibandingkan dengan dua desa lainnya, keanekaragaman vegetasi mengrove di Desa Lokodidi adalah yang tertinggi. Observasi yang dilakukan setidaknya mengidentifikasi 14 jenis mangrove. Di zona belakang (mendekati daratan), terdapat tiga jenis yang paling umum dijumpai yaitu Api-api (Avicennia marina), Pedada (Sonneratia sp.), dan Cengal (Ceriops tagal). Sementara di bagian tengah 
hutan, keanekaragaman mangrove bertambah dengan hadirnya beberapa jenis mangrove lainnya yaitu Bakau (Rhizophora sp.), Bruguiera gymnorrhiza , Xylocarpus granatum, Dolichandhrone spathacea, dan Camptostemon spp. Sementara di sekitar alur sungai, Nipah (Nypa fruticans) terlihat mendominasi penutupan, kadang-kadang diselingi oleh jeruju (Acanthus ilicifolius). Jenis dan kelimpahan mangrove di desa Lokodidi tersaji dalam tabel 2 di bawah ini.

Tabel 2. Jenis dan kelimpahan mangrove di desa Lokodidi

\begin{tabular}{cllcc}
\hline No & \multicolumn{1}{c}{ Jenis } & \multicolumn{1}{c}{ Nama Indonesia } & Nama lokal & Kelimpahan \\
\hline 1 & Sonneratia alba & Pedada putih/ Perepat & Payapat & ++ \\
\hline 2 & Sonneratia caseolaris & Pedada merah/ perepat merah & - & + \\
\hline 3 & Bruguiera gymnorrhiza & Tanjang merah & Tonggi & + \\
\hline 4 & Avicennia marina & Api-api & Peoapi & ++ \\
\hline 5 & Rhizophora apiculata & Bakau sedang / Bakau minyak & - & ++ \\
\hline 6 & Rhizophora mucronata & Bakau besar / Bakau hitam & - & + \\
\hline 7 & Nypa fruticans & Nipah & Kibuy & + \\
\hline 8 & Ceriops tagal & Tengal/ Cengal & Tanga & +++ \\
\hline 9 & Xylocarpus granatum & Nyiri & - & + \\
\hline 10 & Dolichandrone spathacea & - & Tuwele & + \\
\hline 11 & Acanthus ilicifolius & Jeruju & - & + \\
\hline 12 & Camptostemon sp 1 & - & ++
\end{tabular}
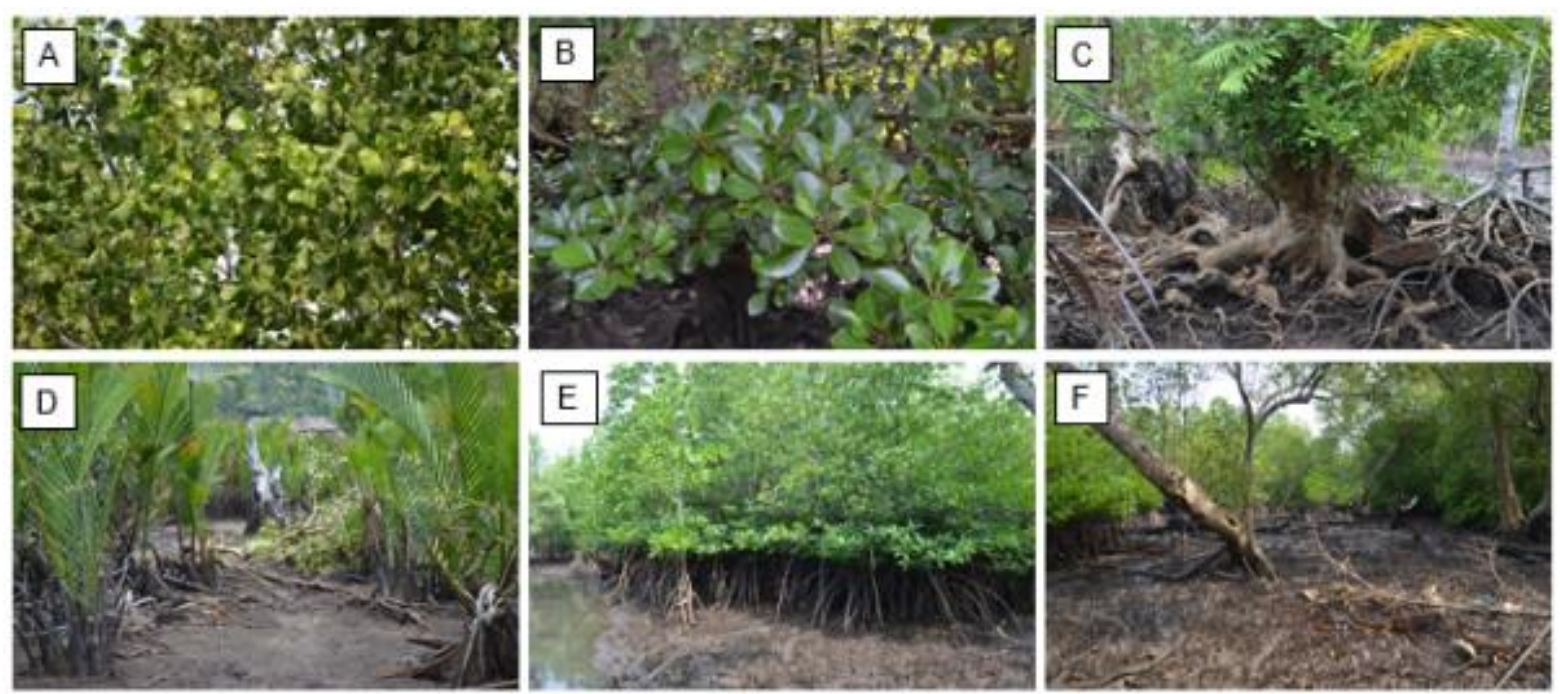

Gambar 10. Jenis-jenis mangrove di Desa Taat yang berhasil didokumentasikan: Sonneratia alba (A), Camptostemon sp.2 (B), Xylocarpus granatum (C), Nypa fruticans (D), Rhizophora mucronata (E), dan Avicennia marina $(\mathrm{F})$.

Kebun kelapa pada umumnya berada di belakang kawasan pemukiman dan lereng bukit. Di wilayah pemukiman, kayu kuda (Lannea caromondalica) dan gamal (Gliricidia sepium) banyak sekali ditanam masyarakat sebagai tanaman pagar. Sedangkan di pekarangan, penduduk lebih cenderung menanam berbagai jenis tanaman yang bernilai estetika (bunga-bungan) dan buah-buahan. Kebun 
campuran pada umumnya terdapat di lereng bukit, seringkali berdekatan atau bahkan bercampur dengan semak belukar dan kebun kelapa. Sementara di kawasan berawa, pohon Sagu (Metroxylon sagu) merupakan jenis tumbuhan yang paling umum dijumpai.

Hasil observasi yang dilakukan di Desa Lokodidi menghasilkan daftar jenis tumbuhan/tanaman yang dikelompokkan ke dalam tipe vegetasi, sebagaimana terangkum dalam lampiran 1.

\section{Isu-isu di pesisir}

\section{Abrasi di Desa Taat}

Tidak semua bagian Desa Taat terlindungi oleh mangrove. Terdapat areal di sebelah timur desa yang mengalami erosi pantai (abrasi) karena lokasi tersebut tidak terlindungi oleh hutan mangrove. Abrasi secara positif telah meningkatkan kesadaran masyarakat betapa pentingnya peran dan fungsi hutan mangrove bagi Desa Taat, terutama dalam memberikan perlindungan dari angin kuat dan abrasi pantai. Di lokasi yang mengalami abrasi, saat ini sedang dilakukan pembangunan tembok pelindung pantai sepanjang $\pm 100 \mathrm{~m}$.

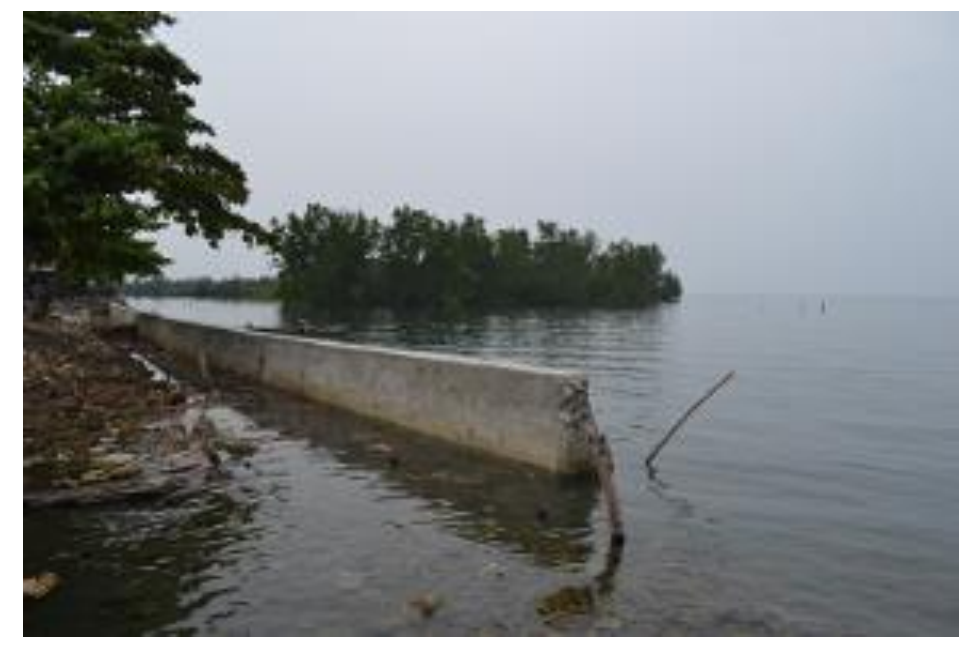

Gambar 11. Tembok pelindung pantai yang sedang dibangun untuk menahan abrasi di Desa Taat

\section{Penambangan emas di hulu sungai Desa Matinan}

Hasil wawancara yang dilakukan di Desa Matinan menyebutkan adanya kegiatan penambangan emas di daerah atas (hulu sungai). Kegiatan ini telah berlangsung sejak lama dan terus berjalan tanpa adanya aturan atau pengaturan dari pihak desa. Beberapa warga menguatirkan dampak dari kegiatan ini mengingat logam berat (air raksa) yang digunakan untuk mencari emas akan mencemari sungai dan berdampak negatif terhadap kesehatan warga desa dalam jangka panjang. Akibat lain dari kegiatan penambangan diantaranya sedimen yang terbawa dari lokasi penambangan juga berpotensi mengakibatkan sedimentasi di area pesisir yang dapat mengganggu pertumbuhan mangrove.

\section{Penambangan pasir di pantai Desa Matinan}

Saat survey dilakukan, dijumpai kegiatan penambangan pasir di areal sekitar koloni pedada sebelah barat Desa Matinan. Kegiatan ini telah berlangsung lama dan dilakukan hampir setiap hari. Kegiatan 
penambangan ini menggunakan tenaga manual, dibantu oleh truk dan gerobak sebagai alat angkut. Sama dengan kasus penambangan emas, tidak ada pengaturan sama sekali atas kegiatan penambangan pasir dari pihak desa.

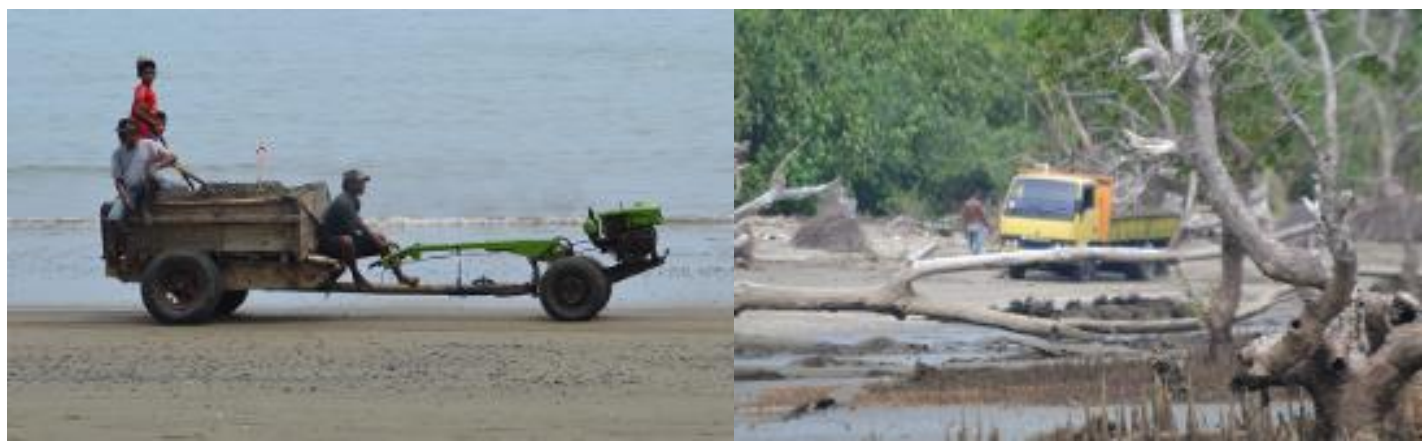

Gambar 12. Penambangan pasir oleh masyarakat

\section{Pengumpulan biji emas di pantai Desa Matinan}

Di musim barat, terdapat kegiatan pencarian biji emas secara masal di sepanjang pantai Desa Matinan. Saat musim barat berlangsung, ratusan orang berduyun-duyun ke pantai untuk mengambil pasir dan menyaringnya untuk mencari emas. Dari wawancara dengan nara sumber, kandungan emas di pantai Desa Matinan diduga kuat berasal dari buangan material sisa penambangan di bagian hulu yang terbawa oleh arus sungai kemudian terkumpul di area pantai.

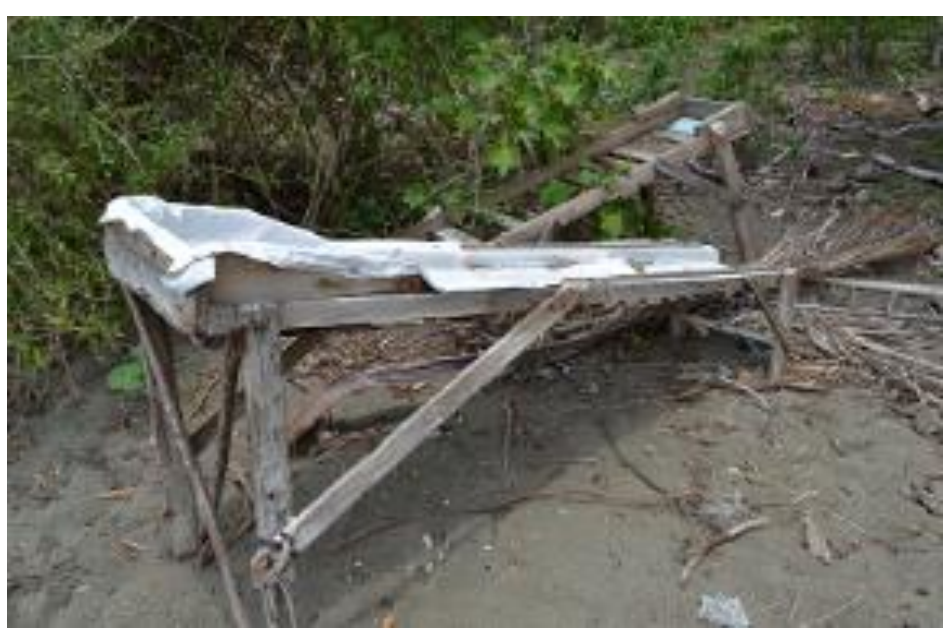

Gambar 13.Alat yang digunakan masyarakat untuk mencari emas

\section{Pembangunan jalan di Desa Lokodidi}

Saat survey dilakukan, pemerintah sedang melakukan pembangunan jalan baru yang menghubungkan dermaga pelabuhan dengan jalan utama. Tahap awal pembangunan telah selesai dimana setengah dari panjang jalan telah selesai dibangun. Saat ini, sedang berlangsung persiapan akhir untuk meyelesaikan proyek ini. Informasi dari kepala desa menyebutkan bahwa pemenang tender telah ditetapkan dan akan segera merealisasikan penyelesaian jalan ini.

Dari simulasi yang didasarkan atas informasi masyarakat dan aparat desa, jalan ini dikuatirkan akan mengkonversi hutan mangrove yang berada di sekitar pemukiman Desa Lokodidi. Sementara dari 
ekspose hasil kajian di Kantor Bapeda tanggal 28 September 2015, diperoleh informasi dari Dishut Kab.Buol bahwa mangrove di Desa Lokodidi berstatus Hutan Lindung (HL). Apabila demikian maka hutan mangrove ini tidak boleh ditebang dengan alasan apapun. Terkait dengan ini, Dinas Pekerjaan Umum dan/atau pengelola proyek perlu berkoordinasi dengan Dinas Kehutanan dan instansi terkait agar hutan mangrove terhindar dari konversi sebagai akibat dari pembangunan jalan ini.

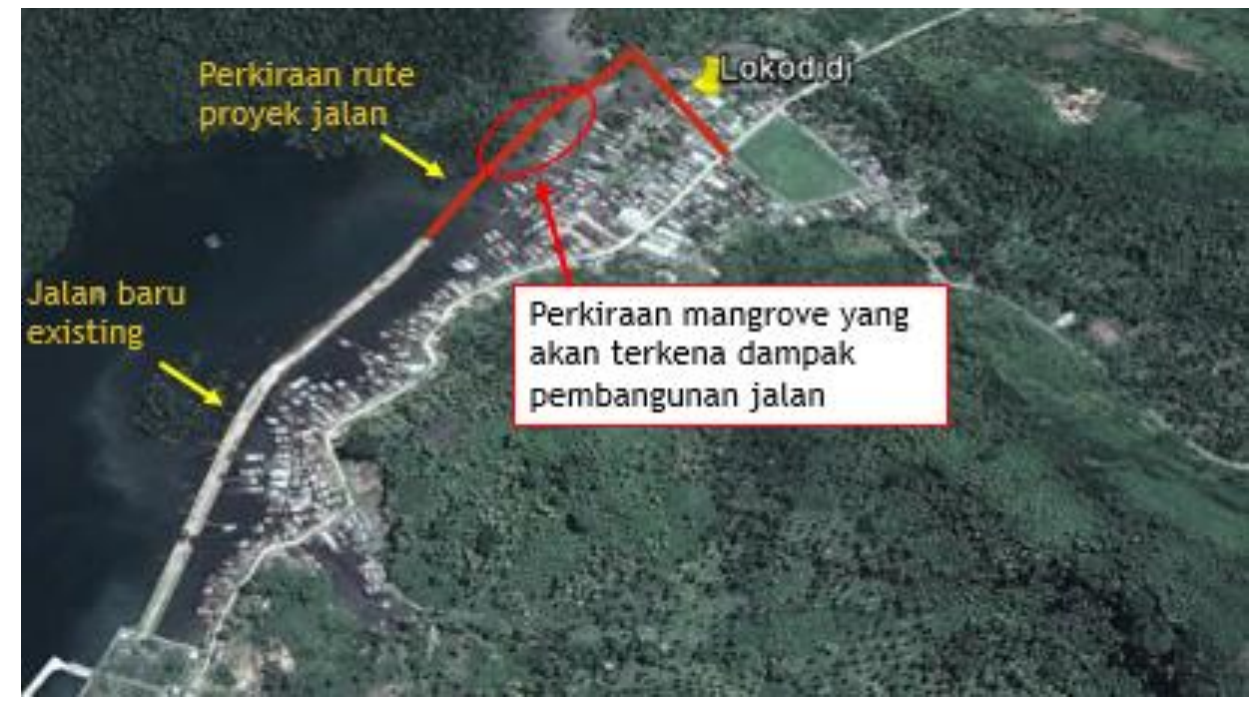

Gambar 14. Potensi dampak proyek pembangunan jalan terhadap hutan mangrove di Desa Lokodidi

\section{Persepsi masyarakat mengenai mangrove dan rehabilitasi}

Masyarakat di ketiga desa memiliki persepsi yang positif terhadap mangrove, terlebih desa Taat dan Lokodidi yang telah merasakan secara langsung fungsi perlindungan yang diberikan hutan mangrove untuk desanya. Selain fungsi perlindungan, masyarakat di tiga desa juga mengetahui dengan baik manfaat ekonomi yang bisa diberikan oleh hutan mangrove.

Dengan kondisi saat ini dimana sebagian hutan mangrove telah terganggu, masyarakat di tiga desa menyambut dengan baik setiap program rehabilitasi yang dilakukan. Lebih jauh, mereka sangat senang untuk dapat dilibatkan didalamnya.

\section{Program rehabilitasi yang pernah dilakukan}

Beberapa program rehabilitasi pernah dilakukan oleh pemerintah di tiga desa. Di bawah ini adalah uraian singkat program-program tersebut.

Di Desa Taat, setidaknya terdapat tiga kali program rehabilitasi mangrove sebagai berikut:

\section{1) Rehabilitasi mangrove melalui Gerakan Rehabilitasi Hutan dan Lahan (GERHAN) tahun 2005}

Dalam program ini, sebanyak 25 ribu tanaman mangrove dibibitkan di persemaian. Namun karena alasan tertentu, hanya sedikit (kurang dari 30\%) yang pada akhirnya ditanam. Tingkat keberhasilan tumbuh program ini sangat rendah. Hama ternak dan rendahnya realisasi penanaman menjadi faktor utama rendahnya keberhasilan tumbuh tanaman di lapangan. 


\section{2) Rehabilitasi mangrove melalui program Kebun Bibit Rakyat (KBR) tahun 2010/11}

Berdasarkan informasi dari nara sumber, program ini merupakan penyulaman terhadap tanaman GERHAN 2005, dimana sebanyak 12 ribu bibit ditanam. Namun demikian, terminologi penyulaman dinilai kurang tepat karena kegiatan ini lebih cenderung melakukan penanaman ulang sebagai akibat gagalnya program sebelumnya.

Dalam program ini, pemerintah menggandeng Kelompok Kuda Laut yang mayoritas anggotanya adalah nelayan. Menyadari adanya ancaman ternak, maka kelompok sepakat untuk memasang pagar. Namun sayang, anggaran yang ada saat itu tidak memungkinkan untuk melakukan pengadaan pagar. Dalam keterbatasan ini, Ketua Kelompok Tani (kades terpilih) mendonasikan jaring tambang untuk dibuat sebagai pagar pelindung. Namun sayang, pagar yang dibuat ternyata tidak mampu menghalau ternak sehingga dapat masuk, memakan daun mangrove, dan menyebabkan kematian tanaman. Aktifitas masyarakat dan lalu lalang perahu menyebabkan pagar yang dibangun menjadi rusak sehingga hewan ternak dapat memasuki lokasi penanaman. Dokumentasi program KBR 2010/11 dapat dilihat melalui gambar di bawah ini.
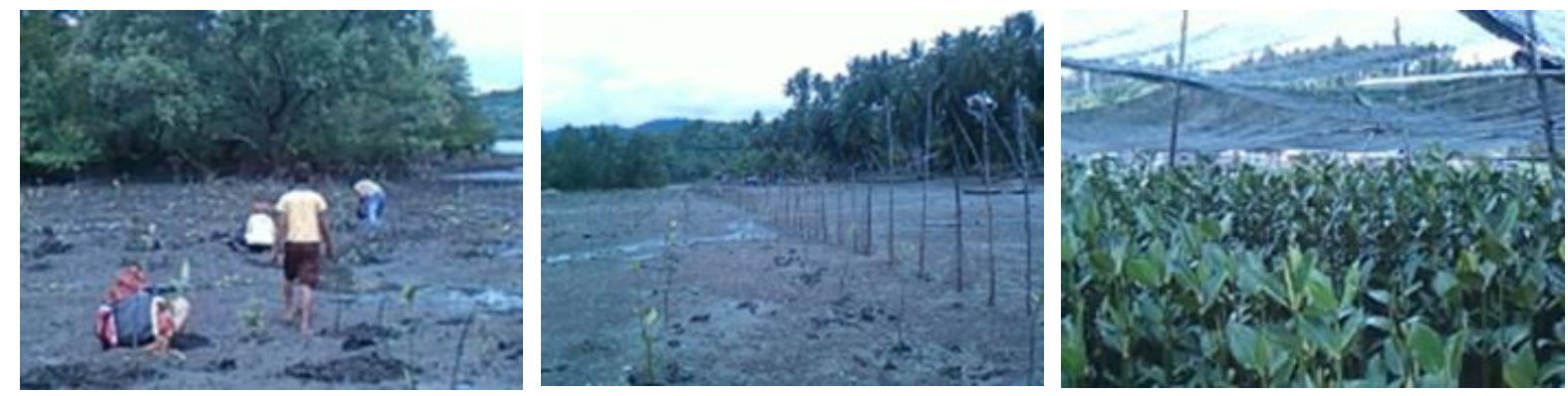

Gambar 15. Pelaksanaan program KBR tahun 2010/11 (dokumentasi pribadi Ketua Kelompok Kuda Laut/Bp. Kades Desa Taat terpilih)

\section{3) Rehabilitasi mangrove melalui program KBR tahun 2014}

Upaya penggalian informasi detail mengenai program ini tidak berhasil di lakukan di lapangan. Namun demikian terlihat di lapangan bahwa kegiatan tahun 2014 relatif sama dengan program sebelumnya. Dalam hal ini, mangrove ditanam di satu hamparan dan diberi pagar untuk menghindari ancaman ternak. Berdasarkan pengamatan di lapangan, persentase tanaman mangrove yang tumbuh dari kegiatan ini rendah. Banyak sekali mangrove mati dengan tanda-tanda serangan ternak. Di beberapa titik, dijumpai pagar pelindung mengalami kerusakan sehingga dapat dimasuki oleh ternak.
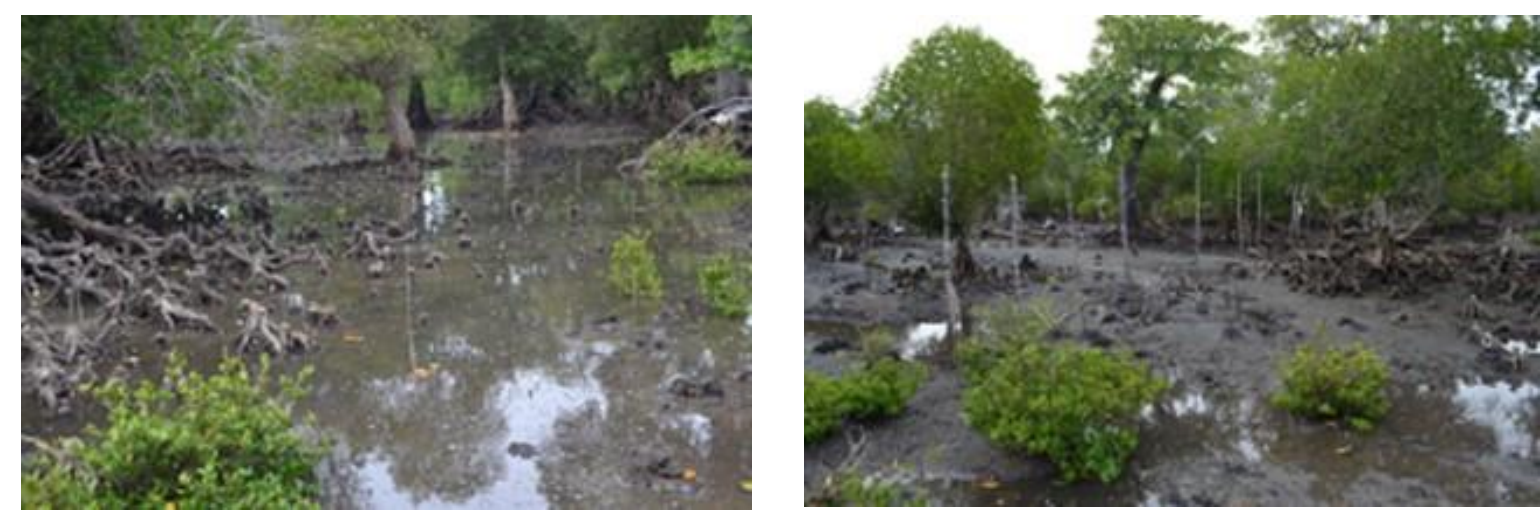

Gambar 16. Tanaman mangrove yang mati (kiri), pagar yang telah rusak (kanan) dalam kegiatan rehabilitasi mangrove 2014 (KBR) 
Di Desa Lokididi, terdapat dua kali program rehabilitasi mangrove sebagai berikut:

1) Rehabilitasi mangrove melalui Gerakan Rehabilitasi Hutan dan Lahan (GERHAN) tahun 2010/11

Dalam program ini sebanyak 12 ribu tanaman mangrove tanam. Lokasi yang ditanam adalah areal berhutan, dimana penanaman di lakukan disela-sela tegakan pohon. Namun sayang keberhasilan tumbuh program ini sangat rendah. Berdasarkan diskusi dengan salah satu pelaksana kegiatan, tinggi dan kuatnya gelombang banyak menghanyutkan biit-bibit yang ditanam.

2) Rehabilitasi mangrove malalui Program Kebun Bibit Rakyat (KBR) tahun 2014

Dalam program KBR ini sebanyak 10 ribu tanaman mangrove tanam. Lokasi yang ditanam adalah lokasi yang sama dengan program sebelumnya. Keberhasilan tumbuh dari program ini juga rendah. Tinggi dan kuatnya air pasang adalah penyebab utama dari rendahnya persentase tumbuh tanaman.

Program rehabilitasi di Desa Lokodidi meninggalkan kekecewaan masyarakat terutama yang terilibat secara aktif. Hal ini karena tidak adanya tindak lanjut dan anggaran khusus dari proyek setelah penanaman. Sementara disisi lain, mereka dituntut untuk menyampaikan perkembangan hasil monitoring tanaman.

Di Desa Matinan, belum pernah ada program rehabilitasi mangrove sama sekali. Informasi yang digali di lapangan menyebutkan bahwa Desa Matinan pernah beberapa kali mendapatkan bantuan bibit dan saprodi (sarana produksi padi) dari pemerintah. Bibit yang diberikan ini lebih banyak jenis-jenis tanaman pertanian, perkebunan, dan jenis tanaman keras daratan (misal: Jati putih (Gmelina arborea) dan Mahoni (Switenia mahagony)).

\section{Kapasitas teknis masyarakat}

Masyarakat Desa Matinan tidak memiliki pengalaman sama sekali dalam mengelola kegiatan rehabilitasi mangrove. Sementara di Desa Taat dan Lokodidi, sebagian anggota masyarakat memiliki pengalaman dari keterlibatannya dalam kegiatan rehabilitasi mangrove. Wawancara dengan masyarakat menyebutkan bahwa mereka tidak pernah dilatih sebelum pelaksanaan kegiatan. Namun berdasarkan staf Dinas Kehutanan Kab. Buol, beberapa anggota masyarakat pernah memperoleh pelatihan rehabilitasi dari pemerintah.

Terlepas dari benar atau tidaknya realisasi pelatihan, kemampuan teknis masyarakat terkait dengan rehabilitasi mangrove dinilai masih rendah. Masyarakat masih belum memahami beberapa hal teknis yang penting dalam rehabilitasi mangrove misalnya teknik pemilihan propagul, teknik persiapan sebelum penanaman, dan teknik pemeliharaan. Hal yang menarik adalah beberapa anggota masyarakat menganggap mereka telah mengerti berbagai hal tentang rehabilitasi, walaupun sebenarnya apa yang mereka ketahui kadang-kadang kurang tepat atau bahkan salah.

Kondisi demikian merupakan salah satu faktor pembatas yang perlu diantisipasi apabila program rehabilitasi mengrove dilakukan di ketiga desa. Kendala ini bisa diatasi dengan memberikan pelatihan teknis dan pendampingan lapangan. 


\section{Identifikasi para pihak}

Dari pemetaan para pihak yang dilakukan, teridentifikasi setidaknya delapan (8) pihak yang memiliki peran dalam kegiatan rehabilitasi pesisir sebagai berikut:

1) Badan Pengelola Daerah Aliran Sungai (BP DAS)

BP DAS Palu Poso merupakan institusi kunci dengan tingkat kepentingan dan pengaruh yang paling tinggi. Hal ini mengingat merekalah yang setiap tahun merancang sekaligus mengimplementasikan program rehabilitasi (Gerhan, KBR) diseluruh bagian wilayah DAS, termasuk di Desa Taat dan Lokodidi. Tanpa adanya peran BP DAS, maka kegiatan rehabilitasi mangrove akan sulit terlaksana. Dalam perencanaan dan penyelengaraan rehabilitasi, BP DAS senantiasa berkoordinasi dengan Dinas Kehutanan.

\section{2) Dinas Kehutanan (Dishut)}

Bersama dengan BP DAS, Dinas Kehutanan Kebupaten Buol memilki peran penting dalam perencanaan dan penyelenggaraan kegiatan rehabilitasi. Dinas Kehutanan memilliki data dan informasi yang terkait dengan status kawasan, database lahan kritis, serta staf yang mampu menjangkau lapangan.

3) Pemerintah Desa

Sebagai pemangku kawasan, pemerintah desa memiliki peran penting dalam terselenggaranya kegiatan rehabilitasi. Tanpa persetujuan dan dukungan pemerintah desa, maka kegiatan rehabilitasi akan sulit terlaksana di desa.

\section{4) Kelompok Masyarakat}

Kelompok masyarakat merupakan mitra strategis bagi setiap program rehabilitasi. Berdasarkan pengalaman yang ada di Desa Taat dan Lokididi, mereka terlibat secara langsung di lapangan terutama dalam kegiatan pembibitan dan penanaman.

5) Pokja DAS

Kelompok Kerja DAS memiliki potensi untuk diberdayakan karena beranggotakan beberapa SKPD di lingkungan Kabupaten BUOL. Pokja ini dapat dioptimalkan untuk diarahkan pada isyu-isyu pesisir terutama konservasi dan rehabilitas mangrove di ketiga desa sasaran.

6) Dinas Kelautan dan Perikanan (DKP)

Meskipun tidak sekuat BP DAS dan Dishut, DKP Kabupaten Buol juga memiliki peran yang cukup penting dalam pengelolaan mangrove, terutama untuk wilayah yang merupakan kawasan budidaya (di luar kawasan hutan). Beberapa program pemberdayaan nelayan memiliki potensi untuk diintegrasikan dengan kegiatan rehabilitasi mangrove. Apabila terdapat kegiatan mina tani (silvofishery), maka peran DKP akan lebih dibutuhkan.

7) Badan Lingkungan Hidup (BLH)

BLH Kabupaten Buol memiliki peran dalam memastikan bahwa isyu-isyu lingkungan terkelola dengan baik, termasuk upaya rehabilitasi yang dilakukan. Dalam kasus pembangunan jalan di Lokodidi, BLH berperan aktif untuk memastikan bahwa kegiatan ini tidak berdampak terhadap lingkungan dan masyarakat setempat. 


\section{8) Badan Perencanaan Pembangunan Daerah dan Penanaman Modal (BAPPEDA-PM)}

BAPPEDA-PM Kabupaten Buol memiliki peran yang penting terutama dalam mengkoordinir perencanaan beberapa SKPD di lingkungan Kabupaten Buol, termasuk didalamnya rehabilitasi pesisir. Dengan proses yang dikoordinir oleh BAPPEDA-PM, beberapa kegiatan dari SKPD dapat dihindarkan dari overlapping atau tumpang tindih.

Dalam konteks rehabilitasi peisisir, masing-masing pihak tersebut diatas memiliki peran masingmasing dengan "tingkat pengaruh" dan "tingkat penting" yang berbeda-beda sebagaimana tersaji dalam gambar 17 di bawah ini.

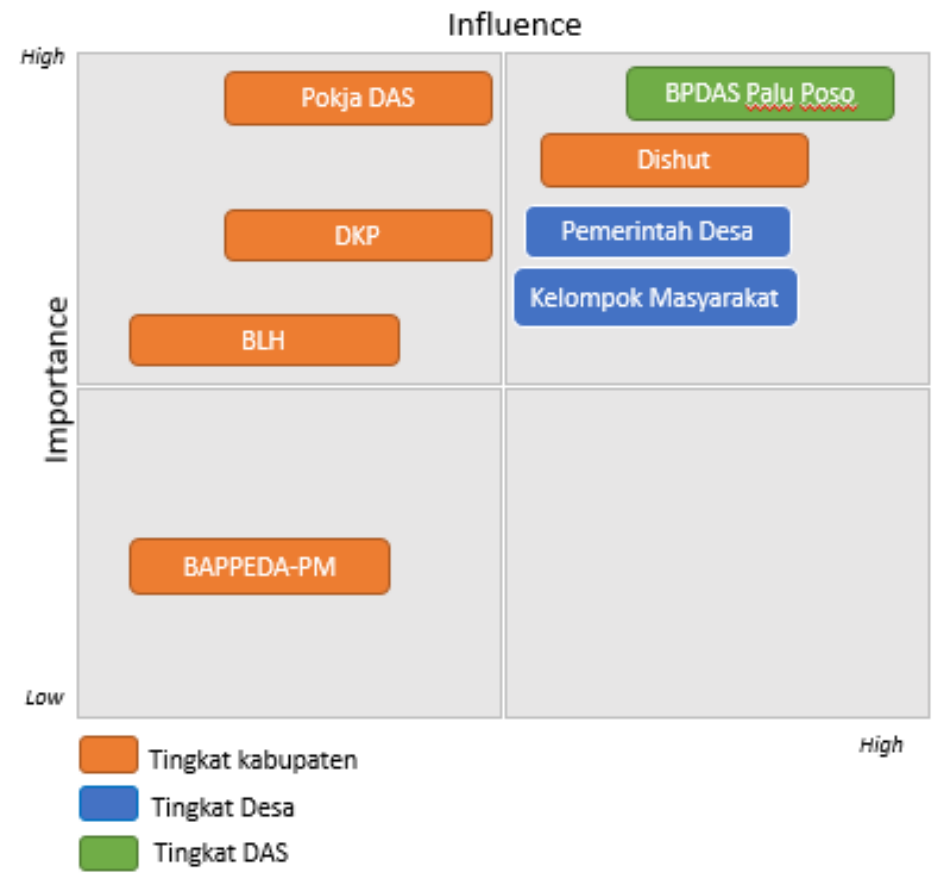

Gambar 17. Hasil pemetaan pihak dalam konteks rehabilitasi pesisir

\section{Informasi lain}

Saat kunjungan di lakukan di Desa Lokodidi, Kepala Desa menyampaikan bahwa Kabupaten Buol telah memiliki Peraturan Daerah (Perda) tentang Perlindungan Pesisir. Dengan alasan ini, menurut kades, maka Peraturan Desa (Perdes) mengenai perlindungan mangrove tidak diperlukan lagi. Menurut Kades, setiap desa tinggal mengimplementasikan di lapangan.Namun dari diskusi yang dilakukan dengan beberapa instansi terkait (Dishut, BLH, DKP), perda yang dimaksud ternyata belum ada. Informasi dari masyarakat beberapa tahun yang lalu pernah ada pembahasan, namun demikian tidak berlanjut karena alasan yang belum diketahui. 


\section{Analisis Kelayakan dan Rekomendasi Teknis Rehabilitasi Pesisir}

\section{Hasil analisis dan rekomendasi desain teknis untuk Desa Taat}

\section{Analisis kelayakan rehabilitasi}

Kajian ini mengidentifikasi beberapa kekuatan yang bersumber dari dalam desa Taat yaitu persepsi positif masyarakat terhadap mangrove dan rehabilitasi, ketersediaan lokasi untuk penanaman mangrove, memiliki pengalaman rehabilitasi, dukungan penuh dari aparat desa, dan ketersedian sumber bibit. Disisi yang lain, terdapat juga peluang dimana masyarakat bisa mendapatkan bantuan dari pemerintah (misalnya: bantuan bibit dari program KBR dari kebupaten). Namun demikian, rendahnya kapasitas teknis masyarakat dan ancaman ternak kambing menjadi dua faktor pembatas yang perlu ditangani dengan baik.

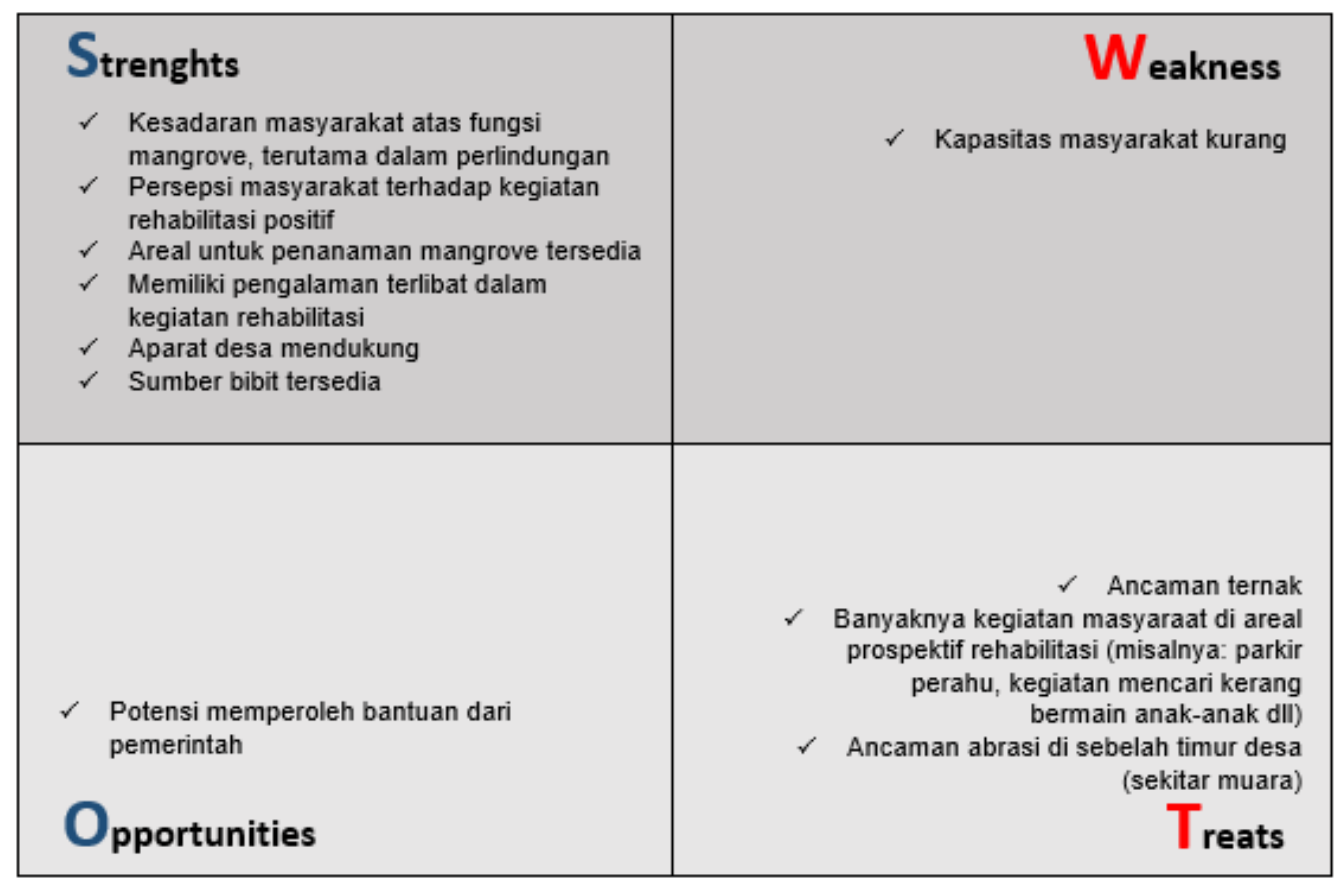

Gambar 18. Hasil analisis SWOT dalam penilaian prospek rehabilitasi di Desa Taat

Dengan banyaknya kekuatan (strenghts) ditambah dengan peluang (opportunity) sebagaimana telah dijelaskan di atas, maka kegiatan rehabilitasi mangrove dinilai layak untuk diimplementasikan di desa ini. Kekuatan dan peluang tersebut harus dapat dioptimalkan, sementara faktor pembatas harus dapat diatasi.

Selain rehabilitasi mangrove, juga direkomendasikan untuk menerapkan teknologi tepat guna $\boldsymbol{H y b r i d}$ Engineering (HE) sebagai upaya mengatasi ancaman abrasi di areal sekitar muara (pantai sebelah timur desa).

\section{Rekomendasi desain teknis}

Di bawah ini adalah desain teknis yang disarankan untuk mendukung kegiatan rehabilitasi mangrove dan penerapan Hybrid Engineeringdi Desa Taat. 


\section{1) Rehabilitasi mangrove}

Dengan mempertimbangkan hasil analisis SWOT maka rehabilitasi mangrove Desa Taat memerlukan suatu inovasi dan perlakuan khusus agar kegiatan rehabilitasi mangrove dapat terselenggara dengan baik dan berhasil.

Inovasi dan perlakukan khusus yang disarakan untuk rehabilitasi mangrove di Desa Taat adalah sebagai berikut :

A. Teknik penanaman

Berdasarkan pengalaman program rehabilitasi di desa ini (tahun 2010, 2011 dan 2014), diketahui bahwa penanaman secara intensif dalam satu hamparan selalu berujung pada kegagalan. Ternak (terutama kambing) dan aktifitas penduduk di lokasi rehabilitasi merupakan penyebab utama kegagalan program-program tersebut.

Atas dasar hal tersebut di atas, maka direkomendaskan untuk menerapkan penanaman dengan "sistem koloni”. Sistem koloni ini diterapkan dengan menanam bibit atau propagul mangrove pada suatu tapak berukuran kecil menyerupai koloni. Mangrove ditanam dengan jarak tanam rapat antara 0.5 hingga 1 meter, kemudian dilindungi dengan pagar pelindung. Luas setiap koloni bisa bervariasi, disarankan berisi antara 30-70 tanaman. Namun demikian, jumlah tanaman di dalam setiap koloni ini bisa saja kurang atau lebih, tergantung dengan kondisi di tingkat tapak.

Berdasarkan diskusi dengan penduduk desa, tiang pagar sebaiknya dibuat dari kayu berukuran sedang. Tiang kayu disarankan untuk menggunakan jenis Kayu kuda (Lannea caromondalica) dengan pertimbangan jenis ini memiliki kekuatan untuk bertahan pada kondisi di tapak penanaman yang setiap hari terkena air laut. Sementara untuk bahan pelindung, direkomendasikan untuk menggunakan jaring tambang karena dinilai lebih tahan terhadap air asin.

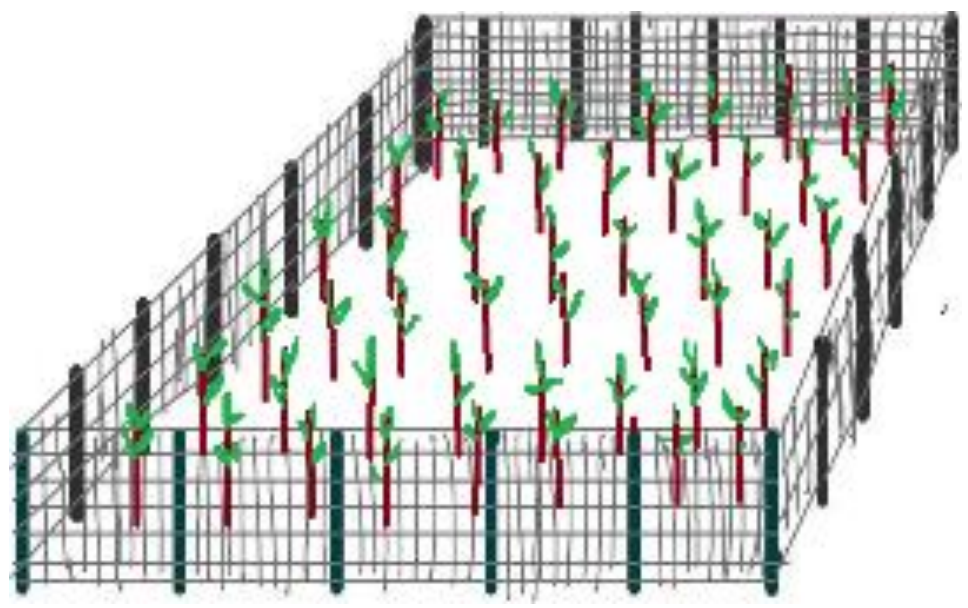

Gambar 19. Ilustrasi sederhana pemagaran koloni tanaman mangrove

Posisi dan ukuran koloni perlu disesuaikan dengan ketersediaan ruangan di lapangan, akses perahu, dan posisi pohon-pohon mangrove yang ada. Gambar di bawah ini merupakan ilustrasi sederhana tentang bagaimana koloni-koloni ini ditempatkan sesuai dengan akses, kondisi substrat, dan tutupan lahannya. 


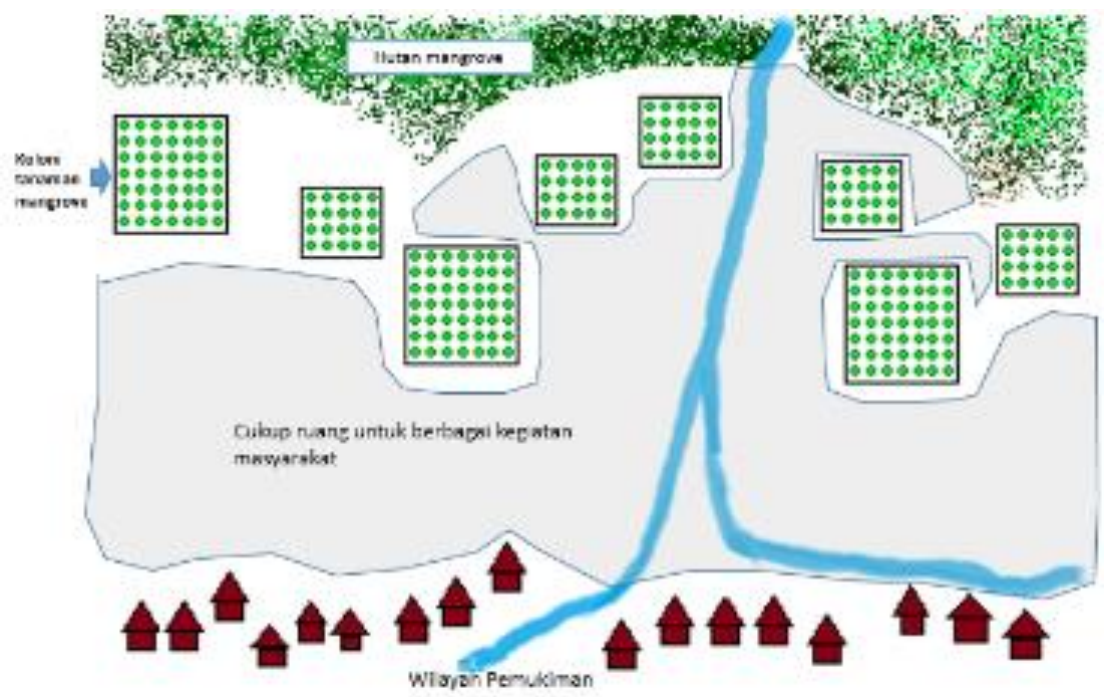

Gambar 20. Ilustrasi sederhana penempatan koloni tanaman mangrove di lokasi penanaman

B. Rekomendasi lokasi target penanaman

Berdasarkan observasi di lapangan, setidaknya terdapat tiga lokasi yang tersedia untuk direhabilitasi di Desa Taat yaitu: 1) hamparan yang berada diantara hutan mangrove dan pemukiman, 2) Areal berlumpur di sekitar pemukiman bagian timur desa, dan 3) areal lumpur berpasir di sekitar muara timur desa. Berdasarkan berdasarkan analisis spasial, luas areal yang tersedia diperkirakan seluas 16.2 ha, dengan perincian sebagai berikut 13 ha (lokasi 1), 0.4 ha (untuk lokasi 2), dan 2.3 ha (lokasi 3).

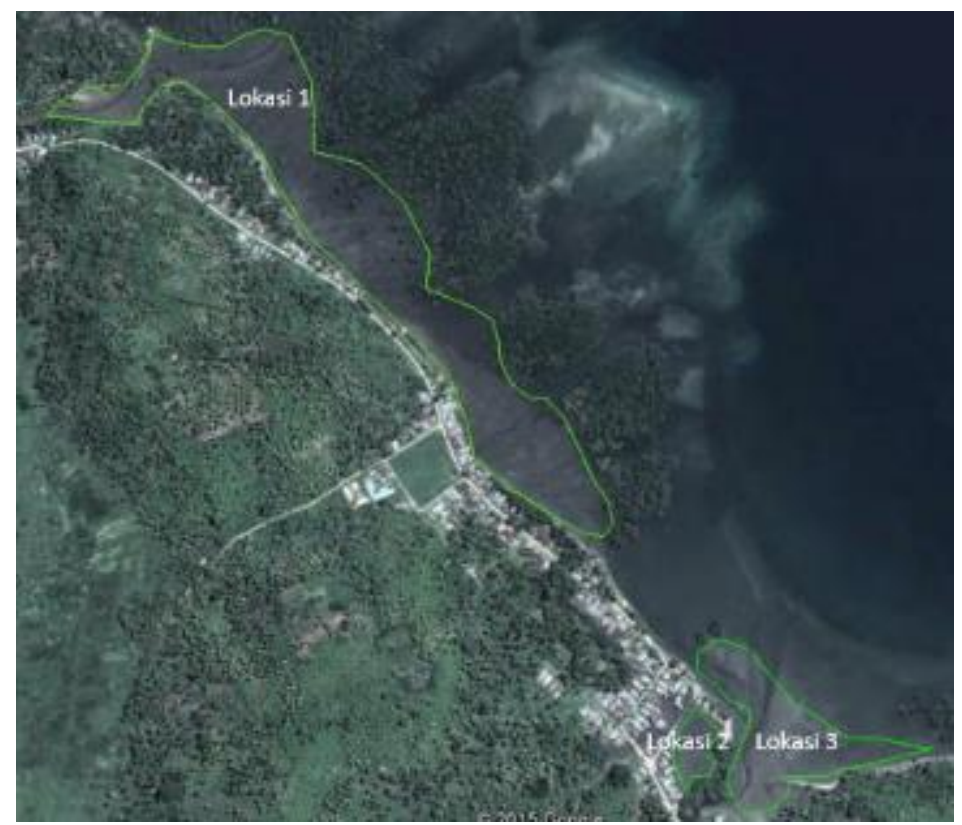

Gambar 21. Areal yang tersedia untuk kegiatan rehabilitasi

Untuk lokasi 1, terdapat tiga kondisi substrat yang berbeda dalam hamparan yang tersedia. Terkait dengan hal ini, maka penanaman sebaiknya difokuskan pada tapak yang memenuhi beberapa syarat di bawah ini: 
- Substrat berlumpur atau lumpur berpasir. Keberadaan lumpur dicirikan oleh adanya ikan gelodok atau tembakul. Substrat pasir lumpur berbatu yang berada di zona belakang sebaiknya dikeluarkan.

- Terkena pengaruh pasang surut

- Lokasi relatif bebas dari aktifitas penduduk

- Status lokasi memungkinkan untuk di rehabilitasi. Apabila milik perseorangan, maka harus dipastikan ada ijin dari pemilik, bila perlu dibuatkan surat perjanjiannya

- Tidak ada rencana untuk mengkonversi lahan tersebut

Untuk lokasi 2, kondisi substrat dan hidrologi dinilai seragam dan memilliki kesesuaian untuk penanaman mangrove. Namun demikian, penempatan lokasi penanaman ini harus di atur dengan memperhatikan hal-hal di bawah ini:

- Tidak berada sejauh $10 \mathrm{~m}$ kanan atau kiri dari sempadan jalan. Hal ini mengingat ada kemungkinan di daerah ini akan dibangun rumah di masa mendatang.

- Status lokasinya memungkinkan untuk ditanami. Apabila milik perseroangan maka diperlukan perjanjian tertulis untuk tidak mengkonversi menjadi peruntukan lain di masa mendatang.

Lokasi 3 sebenarnya memiliki substrat yang sesuai untuk tanaman mangrove yang itu lumpur berpasir. Namun sayang, kondisi ombak di lokasi ini cukup kuat sehingga dikuatirkan akan berpotensi mengganggu tanaman mangrove. Untuk lokasi ini, disarankan untuk mengaplikasikan teknologi Hybird Engineering (HE) sebagai "langkah prakondisi" sebelum penanaman mangrove dapat dilakukan. Informasi lebih lanjut mengenai HE akandi bahas pada sub-bab berikutnya (halaman 30).

Berdasarkan pertimbangan-pertimbangan di atas, maka lokasi yang direkomendasikan sebagai lokasi penanaman mangrove di Desa taat hanya seluas 6.4 hektar sebagai berikut:

- Lokasi 1 yang substratnya berlumpur dan lumpur berpasir. Berdasarkan analisis spasial, areal yang memiliki kesesuaian untuk tanaman mangrove diperkirakan seluas 6.1 ha.

- Lokasi 2 yang berada lebih dari $10 \mathrm{~m}$ dari jalan. Berdasarkan analisis spasial, areal ini diperkirakan seluas 0.3 ha. 


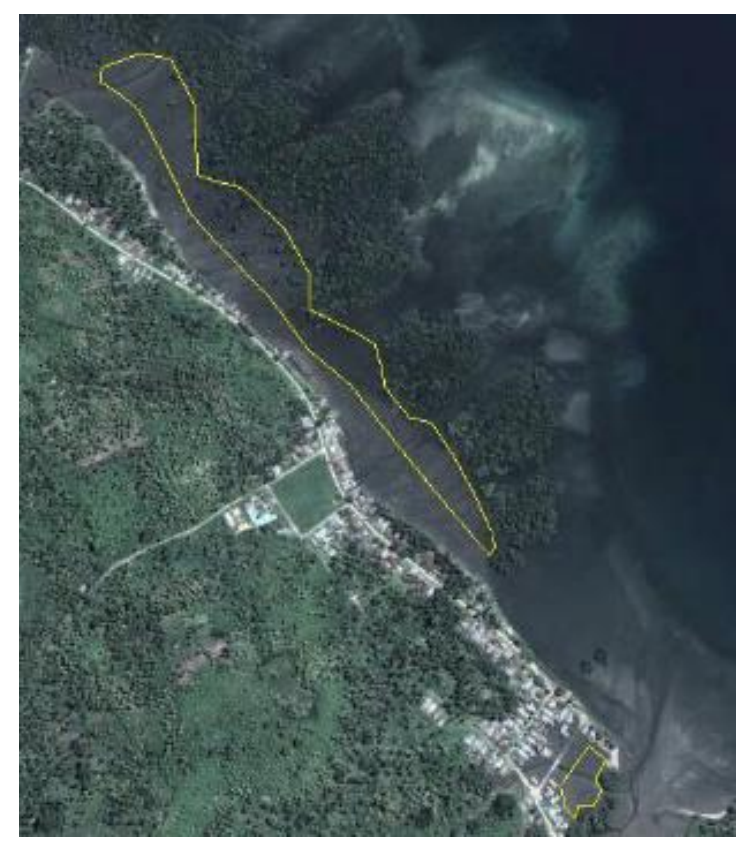

Gambar 22. Lokasi yang direkomendasikan untuk rehabilitasi mangrove di Desa Taat

\section{Catatan:}

Karena sistem penanaman yang diterapkan adalah sistem koloni, maka diperkirakan hanya $\pm 30 \%$ dari luas total yang benar-benar efektif ditanami mangrove (untuk tahap awal). Survey detail dan diskusi dengan masyarakat harus dilakukan untuk menentukan titik titik penanaman koloni.

C. Teknik penanaman mangrove

Sesuai dengan kondisi substrat yang ada di lokasi rehabilitasi, setidaknya terdapat enam jenis mangrove yang bisa dijadikan sebagai opsi dalam program rehabilitasi mangrove di Desa Taat sebagaimana terangkum dalam tabel 3 di bawah ini.

Tabel 3. Jenis-jenis mangrove yang potensial untuk ditanam di Desa Taat

\begin{tabular}{cll}
\hline No & Jenis & Opsi penanaman \\
\hline 1 & Rhizophora mucronata & $\begin{array}{l}\text { Bisa menggunakan bibit jadi (berpolibag) atau bisa juga dengan } \\
\text { menaman propagul secara langsung di lapangan }\end{array}$ \\
\hline 2 & Rhizophora apiculata & $\begin{array}{l}\text { Bisa menggunakan bibit jadi (berpolibag) atau bisa juga dengan } \\
\text { menaman propagul secara langsung di lapangan }\end{array}$ \\
\hline 3 & Avicennia marina & $\begin{array}{l}\text { Bisa menanaman anakan alam dengan sistem coring atau menanam } \\
\text { bibit yang dipersiapkan dari benih }\end{array}$ \\
\hline 4 & Sonneratia alba & $\begin{array}{l}\text { Bisa menanaman anakan alam dengan sistem coring atau menanam } \\
\text { bibit yang dipersiapkan dari benih }\end{array}$ \\
\hline 5 & Ceriops tagal & $\begin{array}{l}\text { Bisa menanaman anakan alam dengan sistem coring atau menanam } \\
\text { bibit yang dipersiapkan dari popagul }\end{array}$ \\
\hline 6 & Bruguiera gymnorrhiza & $\begin{array}{l}\text { Bisa menggunakan bibit jadi (berpolibag) atau bisa juga dengan } \\
\text { menaman propagul secara langsung di lapangan }\end{array}$ \\
\hline
\end{tabular}




\section{2) Penerapan Hybrid Engineering}

Hybrid Eengineering (HE) merupakan teknik sederhana yang bekerja dengan prinsip "membangun bersama alam" (Building With Nature - BWN). Secara sederhana HE mengaplikasikan suatu struktur permeable sebagai piranti untuk mengurangi kekuatan gelombang sekaligus memerangkap sedimen yang terbawa air laut dan/atau alur sungai di daratan. Dalam beberapa bulan, sedimentasi yang terbentuk di belakang struktur permeable diharapkan mampu memberikan kondisi yang ideal untuk permudaan alami (natural regeneration). Untuk mempercepat hadirnya mangrove, penanaman tambahan dapat dilakukan. Dalam beberapa tahun, tanaman mangrove yang tumbuh diharapkan dapat menggantikan peran struktur permeable dalam melindungi garis pantai. Wetlands International pertama kali memperkenalkan konsep ini di Indonesia dan bekerjasama dengan mitra lokal melakukan ujicoba di Demak - Jawa Tengah sejak 2013. Informasi lebih detail mengenai HE dapat di akses pada link di bawah ini:

○ http://www.wetlands.org/News/tabid/66/ID/3452/Hybrid-engineering-to-protect-erodingcoastlines-in-Indonesia.aspx

○ https://www.youtube.com/watch?feature=player_embedded\&v=kju9zAgiO7c

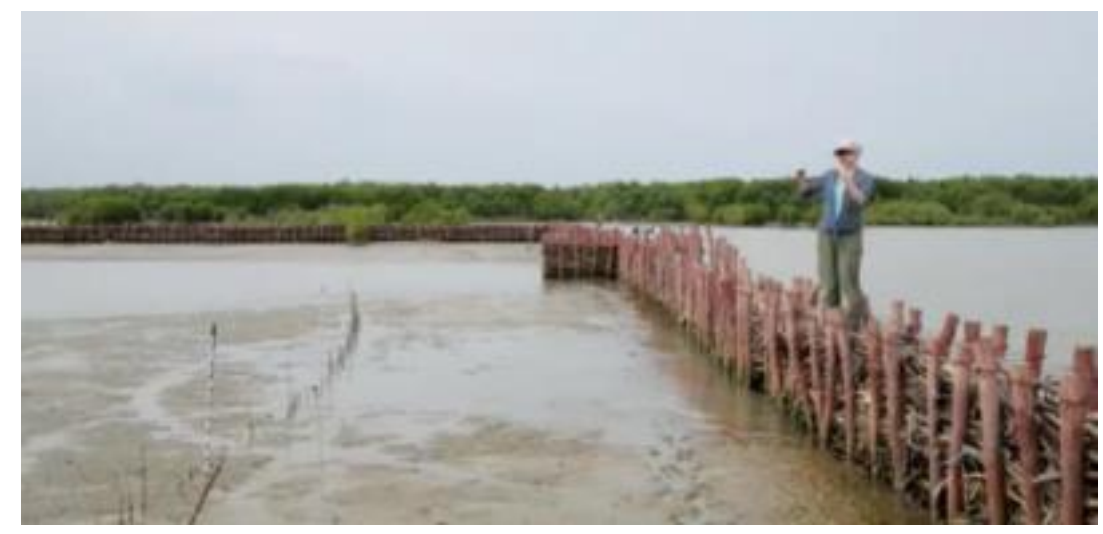

Gambar 23. Contoh penerapan Hybrid Engineering (HE) di Demak-Jawa Tengah (foto: Wetlands International)

Berdasakan observasi di lapangan, teknik Hybrid Engineering (HE) sangat relefan untuk diterapkan di Desa Taat. Penerapan HE diharapkan dapat melindungi garis pantai dari abrasi dan menciptakan kondisi untuk regenerasi mangrove secara alami atau penanaman mangrove. Lokasi yang paling ideal untuk penerapan HE di Desa Taat adalah areal disekitar lokasi 3 yang berada di muara sungai (lihat gambar 24) 


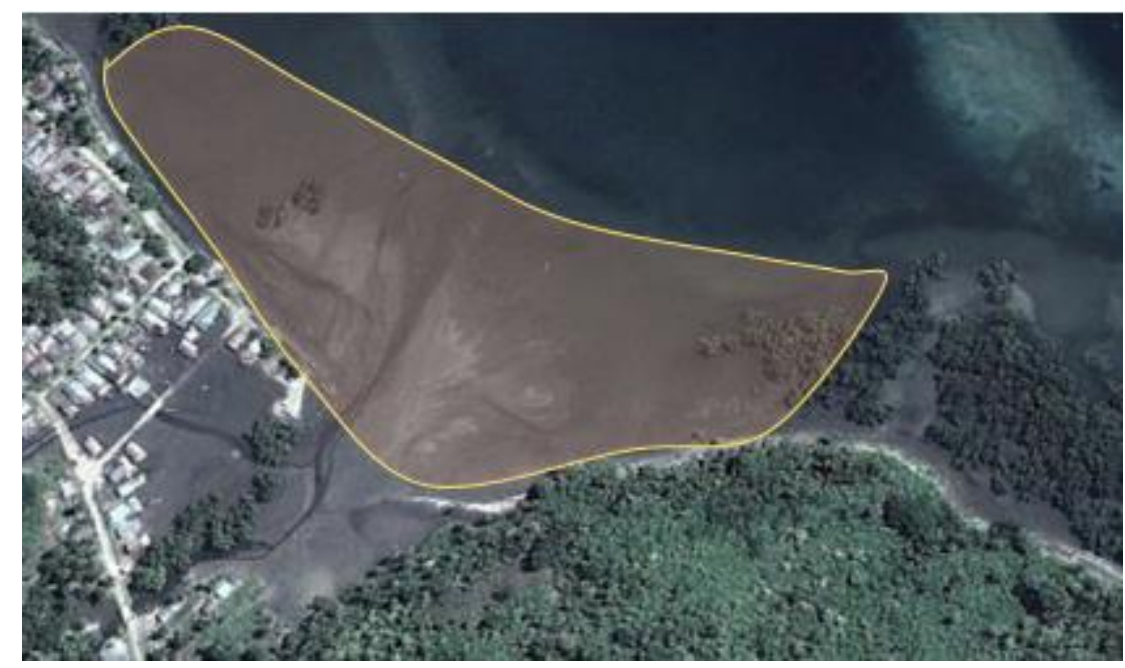

Gambar 24. Lokasi yang direkomendasikan untuk penerapan Hybrid Engineering

Untuk dapat memberikan desain teknis HE secara spesifik di desa Taat perlu ada studi lanjutan mengenai karakteristik oceanografi dan pola sedimentasi baik dari laut maupun yang dari sungai.

\section{Hasil analisis dan rekomendasi desain teknis untuk Desa Lokodidi}

\section{Analisis kelayakan rehabilitasi}

Kajian ini mengidentifikasi beberapa kekuatan yaitu persepsi positif masyarakat terhadap rehabilitasi, ketersediaan lokasi untuk penanaman mangrove dan lokasi percontohan Silvofishery, memiliki pengalaman rehabilitasi, sumber bibit tersedia, dan dukungan dari aparat desa. Hal menarik dijumpai di desa ini adalah adanya proaktifitas beberapa penduduk yang ditunjukkan dengan adanya persemaian mandiri, walaupun dalam hal ini lebih cenderung untuk menangkap peluang ekonomi dari kegiatan rehabilitasi. Selain kekuatan, terdapat juga peluang dimana masyarakat bisa mendapatkan bantuan dari pemerintah (misalnya: bantuan bibit dari pemerintah). Namun demikian, terdapat beberapa faktor pembatas dan ancaman yang perlu untuk ditangani yaitu rendahnya kapasitas teknis masyarakat, ancaman ternak kambing, dan rencana pembangunan jalan yang berpotensi mengkonversi sebagian hutan mangrove. 


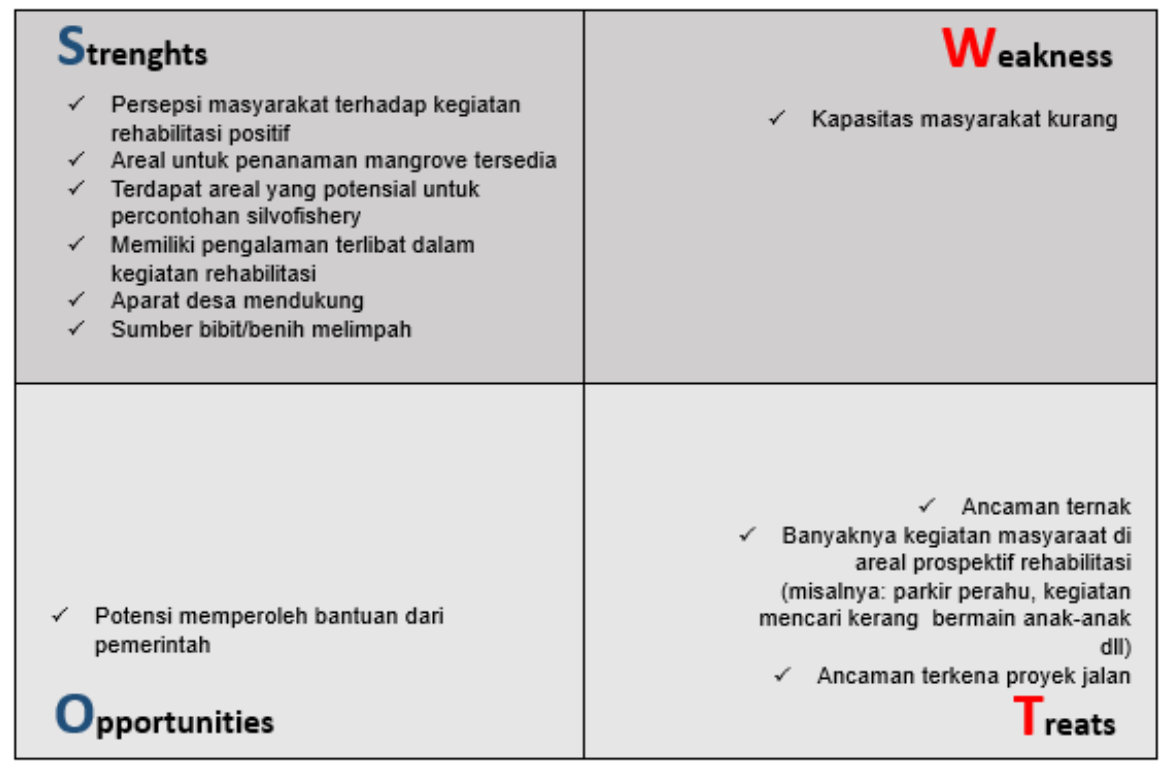

Gambar 25. Hasil analisis SWOT dalam penilaian prospek rehabilitasi di Desa Lokodidi

Dengan mempertimbangkan hasil analisis SWOT di atas maka kajian ini merekomendasikan 1) kegiatan rehabilitasi mangrove dan mempertimbangkan 2) penerapan demosite silvofishery di Desa Lokodidi.

\section{Rekomendasi desain teknis}

Di bawah ini adalah desain teknis yang disarankan untuk mendukung dua kegiatan tersebut di atas.

1) Rehabilitasi mangrove

A. Teknik penanaman mangrove

Dalam rangka mengantisipasi gangguan dari kegiatan penduduk dan ancaman ternak, maka penanaman mangrove di desa Lokodidi juga disarankan untuk menerapkan sistem koloni sebagaimana yang direkomendasikan juga untuk desa Taat (Lihat halaman 25-26).

B. Rekomendasi lokasi target penanaman

Dari kunjungan yang dilakukan di lokasi rehabilitasi pemerintah, diketahui bahwa lokasi penanaman memiliki kondisi tutupannya masih bagus. Dengan kondisi yang masih berupa hutan dengan banyak pohon induk, hutan masih dapat beregenerasi secara alami.Dengan alasan di atas maka program ICRAF sebaiknya tidak menjadikan lokasi di dalam hutan mangrove sebagai target kegiatan rehabilitasi.

Sebaliknya, program sebaiknya dilaksanakan di lokasi lain yang benar-benar memerlukan campur tangan manusia yaitu lokasi yang relatif terbuka dengan kondisi substrat berlumpur yang memungkinan bagi mangrove untuk tumbuh dengan baik. Berdasarkan observasi di lapangan, dijumpai areal seluas 1.5 hektar yang dinilai prospktif untuk dilakukan rehabilitasi. Areal ini tersebar di tiga lokasi berbeda yaitu lokasi $1=0.6$ ha, lokasi $2=0.2$ ha, lokasi $3=0.2$ ha, dan lokasi $4=0.5$ ha. 


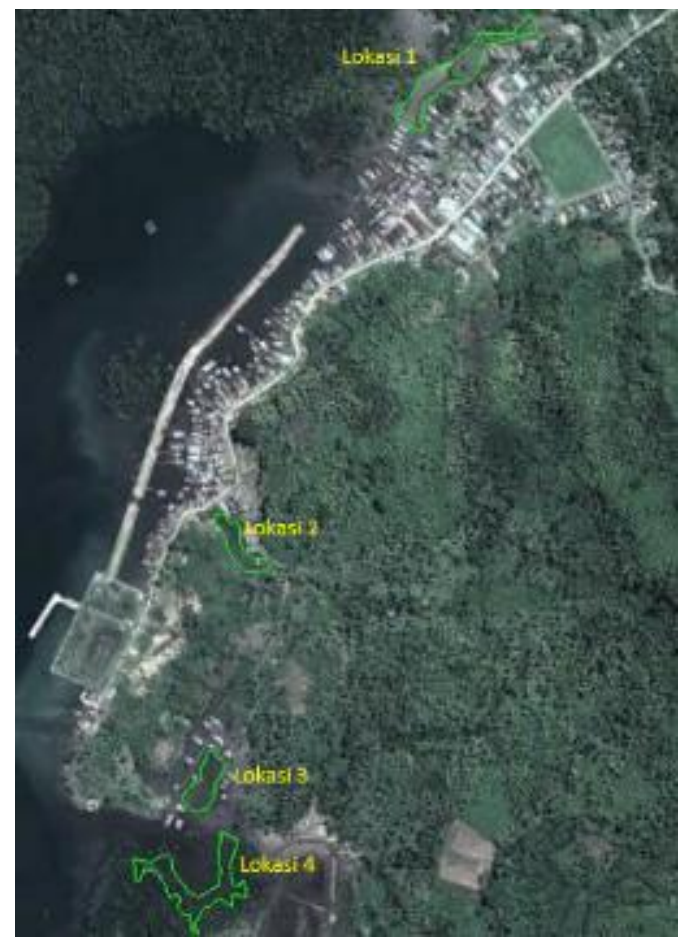

Gambar 26. Lokasi yang direkomendasikan untuk rehabilitasi mangrove di Desa Lokodidi

\section{Catatan:}

○ Untuk lokasi 4, perlu di verifikasi apakah ini masih menjadi bagian desa Lokodidi atau sudah masuk desa tetangga.

- Mengingat teknik penanaman yang disaranan adalah "sistem koloni", maka tidak seluruh lokasi tersebut akan efektif ditanami. Lokasi dan titik penempatan koloni perlu disesuaikan dengan kondisi ruang yang ada, dan tidak mengganggu kegiatan masyarakat. Berdasarkan estimasi, lokasi yang benar-benar efektif untuk ditanam antara $30-40 \%$.

C. Usulan jenis mangrove

Sesuai dengan kondisi substrat yang ada di lokasi rehabilitasi, setidaknya terdapat empat jenis mangrove yang bisa dijadikan sebagai opsi dalam program rehabilitasi mangrove di Desa Lokodidi. Tabel 4 di bawah ini merangkum keempat jenis potensial tersebut.

Tabel 4. Jenis-jenis mangrove yang potensial untuk ditanam di Desa Lokodidi

\begin{tabular}{|c|l|l|}
\hline No & Jenis & Opsi penanaman \\
\hline 1 & Rhizophora mucronata & $\begin{array}{l}\text { Bisa menggunakan bibit jadi (berpolibag) atau bisa juga dengan } \\
\text { menaman propagul secara langsung di lapangan }\end{array}$ \\
\hline 2 & Rhizophora apiculata & $\begin{array}{l}\text { Bisa menggunakan bibit jadi (berpolibag) atau bisa juga dengan } \\
\text { menaman propagul secara langsung di lapangan }\end{array}$ \\
\hline 3 & Ceriops tagal & $\begin{array}{l}\text { Bisa menanaman anakan alam dengan sistem coring atau menanam } \\
\text { bibit yang dipersiapkan dari popagul }\end{array}$ \\
\hline 4 & Bruguiera gymnorrhiza & $\begin{array}{l}\text { Bisa menggunakan bibit jadi (berpolibag) atau bisa juga dengan } \\
\text { menaman propagul secara langsung di lapangan }\end{array}$ \\
\hline
\end{tabular}




\section{2) Pembangunan demosite silvofishery}

Di Desa Lokodidi, terdapat tambak terlantar yang dulunya merupakan hutan mangrove. Hutan mangrove tersebut dikonversi oleh seorang penduduk yang pada akhirnya memperoleh hak kepemilkan dari pemerintah. Berdasarkan analisis spasial, tambak terlantarini diperkirakan seluas 1.9 hektar dengan perimeter 796 meter.

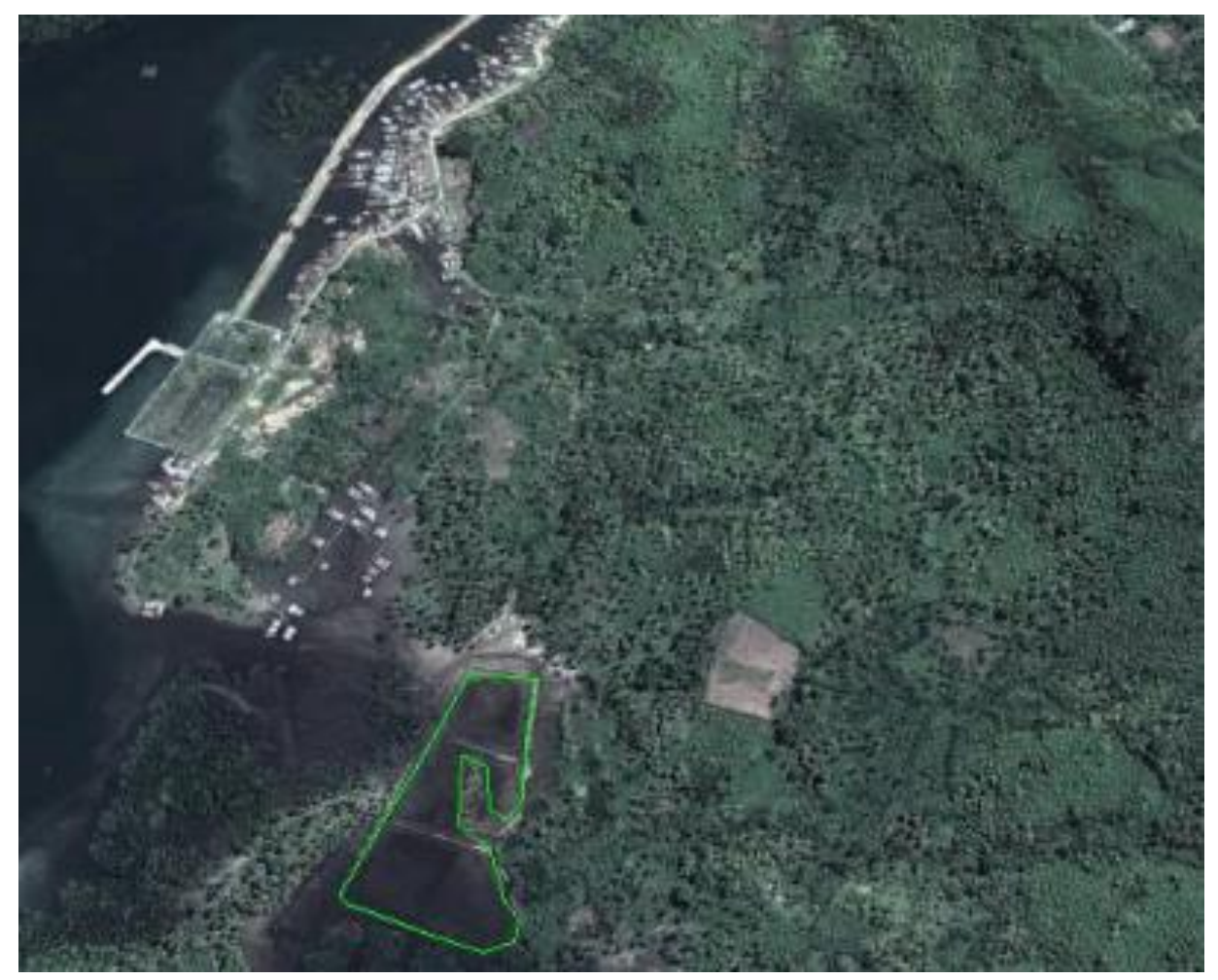

Gambar 27. Tambak terlantar yang miliki potensi untuk dijadikan demosite silvofishery

Di masa-masa awal operasional tambak, kegiatan budidaya udang berjalan dengan baik. Namun beberapa tahun kemudian, hasil tambak mengalami penurunan dan pada akhirnya dibiarkan terlantar. Informasi lain yang diperoleh dilapangan menyebutkan bahwa tidak beroperasinya tambak ini dikarenakan tenaga kerja yang pulang ke kampung dan tidak kembali lagi.

Untuk merealisasian tambak silvofisery, maka infrastruktur tambak (terutama pintu air dan pematang tambak) harus diperbaiki terlebih dahulu agar tambak dapat aktif kembali. Apabila pematang telah terbangun, maka penanaman mangrove dapat dilakukan di sepanjang tepinya (gambar 28).

Penanaman ini dapat dilakukan dengan jarak tanam yang rapat antara $20-50 \mathrm{~cm}$, dan bisa dilakukan hingga dua baris. Dan apabila memungkinkan, penanaman tambahan di dalam tubuh air (dalam tambak) juga bisa dilakukan dengan sistim jalur (gambar 29). 


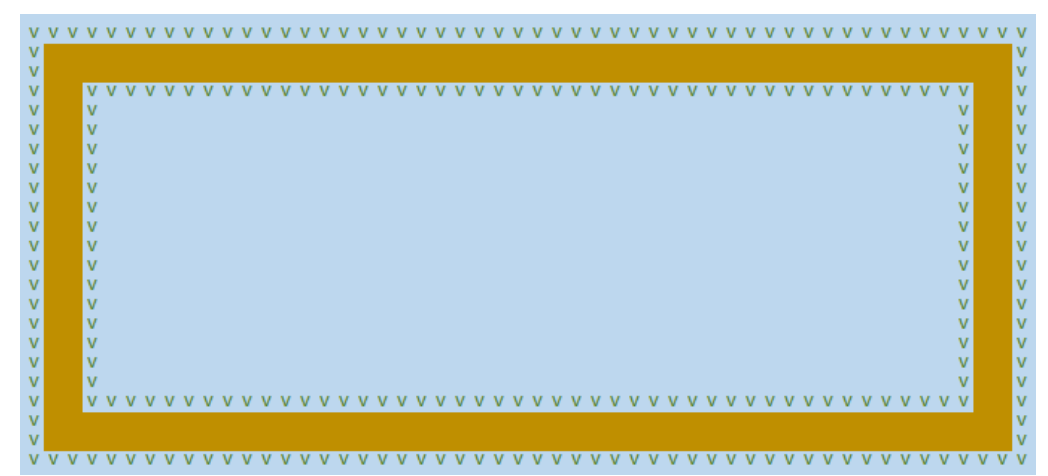

Gambar 28. Penanaman mangrove di sepanjang pematang tambak

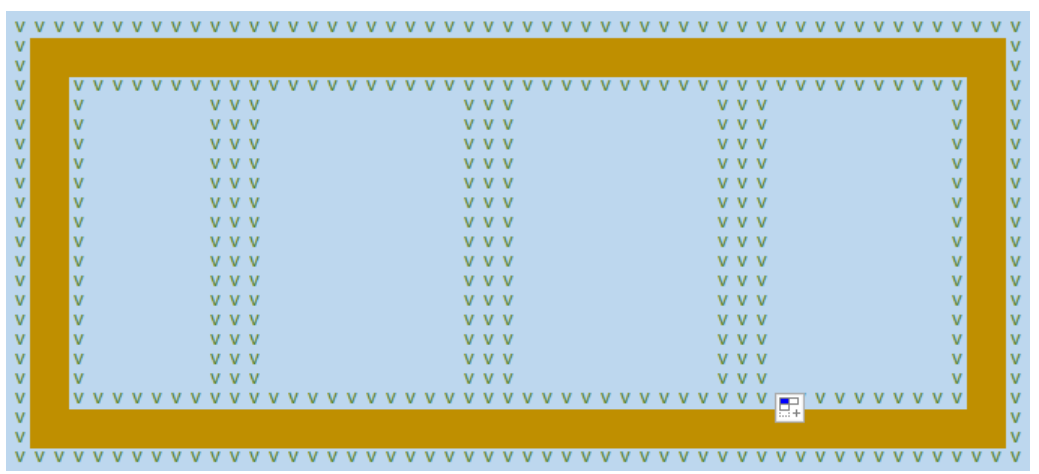

Gambar 29. Penanaman mangrove di sepanjang tambak, dikombinasikan dengan sistem jalur

Untuk di areal tambak, penanaman sebaiknya menggunakan Rhizophora mucronata, Rhizopora apiculata, atau Rhizophora stylosa. Hal ini dikarenakan akar ketiga jenis ini dapat memperkuat struktur tanah di sepanjang pematang. Penanaman dengan jenis Avicennia spp. dan Sonneratia spp. sebaiknya dihindarkan karena akarnya dapat menjalar ke segala arah sehingga mengganggu operasional tambak.

Namun demikian, opsi pengembangan silvofishery ini harus dipertimbangan secara matang mengingat tambak ini adalah milik perseorangan. Apabila ini dilakukan, maka manfaat atau benefit dari kegiatan ini akan dinikmati oleh pemilik secara terbatas. Opsi ini akan lebih menarik apabila kegiatan silvofishery ini dapat dikelola secara bersama oleh kelompok sehingga manfaat yang diperoleh dari silvofishery akan lebih nyata dan berkelanjutan.

Untuk menunjang pengambilan keputusan penerapan demosite di Desa Lokodidi, diperlukan beberapa kajian antara lain alternatif komoditas perikanan, penerimaan masyarakat terhadap konsep silvofihersy, dan potensi dampak dari penerapan silvofishery. Apabila berdasarkan hasil kajian mengindikasikan lebih banyak manfaat secara ekonomis dan berdampak positif terhadap lingkungan dan sosial, maka demosite silvofishery dapat diaplikasikan di desa ini.

\section{Hasil analisis dan rekomendasi desain teknis untuk Desa Matinan}

\section{Analisis kelayakan rehabilitasi}

Mengingat karakteristik pesisir Desa Matinan yang dominasi pantai berpasir, maka rehabilitasi mangrove secara intensif tidak memungkinkan untuk dilakukan. Namun disisi lain, desa ini memiliki 
ruang terbuka di sekitar desa yang perlu untuk dihijaukan. Desa ini juga menyimpan beberapa kekuatan yaitu persepsi positif masyarakat terhadap kegiatan rehabilitasi dan dukungan penuh dari aparat desa. Peluang untuk memperoleh bantuan dari pemerintah menampak sisi positif terhadap prospek rehabilitasi pesisir. Meskipun demikian, rendahnya kapasitas teknis masyarakat dan kegiatan penambangan di pantai perlu mendapatkan perhatian ekstra.

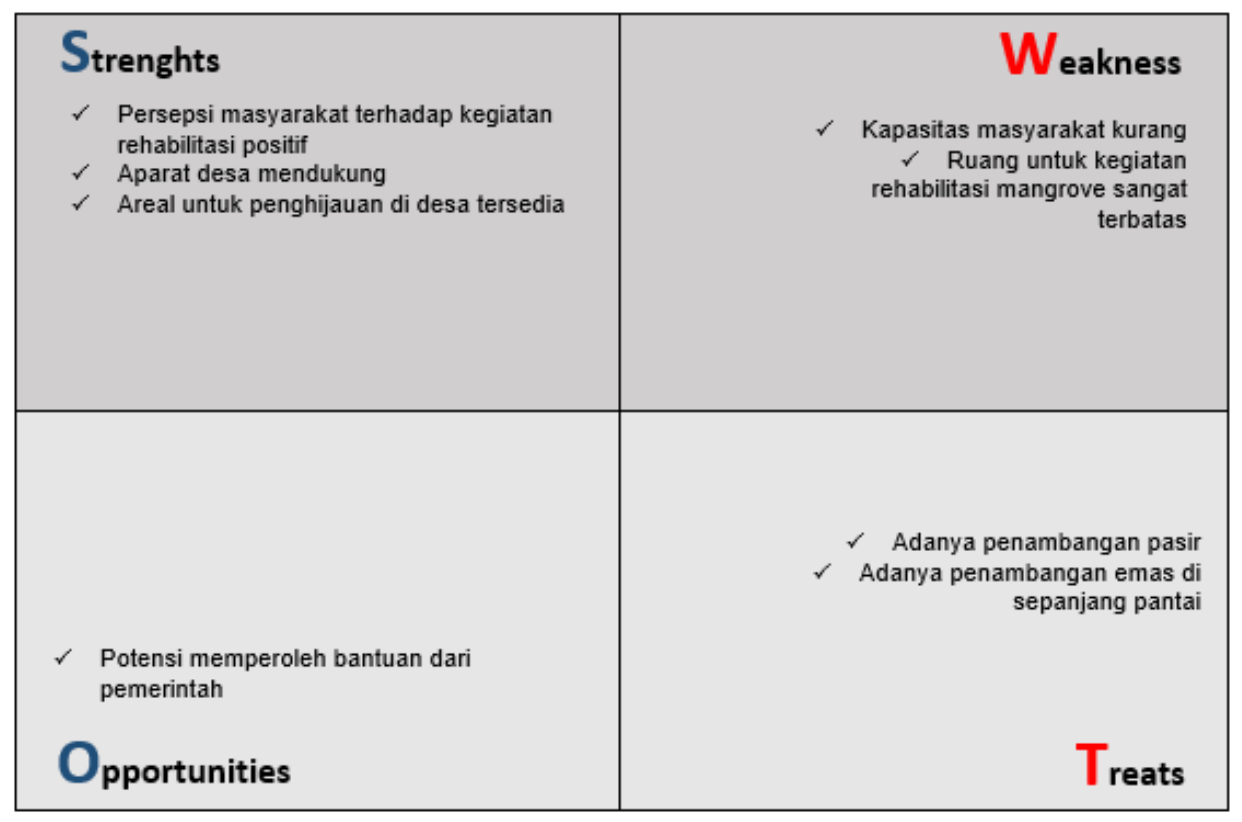

Gambar 30. Hasil analisis SWOT dalam penilaian prospek rehabilitasi di Desa Matinan

Mengingat tidak adanya areal berlumpur di sepanjang pantai Desa Matinan, maka kegiatan rehabilitasi mangrove secara intensif tidak direkomendasikan. Untuk melakukan penanaman di sekitar koloni pedada-pun sangat sulit dilakukan karena terkendala ombak yang tinggi dan sedimentasi pasir.

\section{Rekomendasi teknis}

Berdasarkan hasil analisis SWOT di atas, direkomendasikan untuk melakukan pengkayaan mangrove (mangrove enrichment). Kegiatan ini mengacu pada penanaman jenis-jenis mangrove yang tidak dijumpai di lokasi penanaman (atau ada namun sangat terbatas) agar tegakan mangrove yang ada menjadi lebih kaya jenis.

Kegiatan ini disarankan untuk tegakan nipah sekitar muara barat dan api-api sekitar di muara sungai bagian timur desa Matinan. Namun demikian, volume kegiatan pengayaan ini relatif terbatas karena terbatasnya areal yang memungkinkan untuk ditanami.

1) Pengkayaan di tegakan nipah

Untuk pengayaan tegakan nipah, disarankan menanam Rhizophora mucronata, Rhizophora apiculata, Rhizophora stylosa, Ceriops tagal, Camptostemon spp., dan Xylocarpus granatum. Penanaman ini dapat dilakukan di areal kosong di sela-sela tegakan nipah, dengan jarak tanam 50x $50 \mathrm{~cm}$ (lihat gambar 31). Sumber bibit untuk jenis-jenis tersebut daat diperoleh di Desa Taat atai Lokodidi. Dari 0.1 ha, diperkirakan hanya $20 \%$ saja yang dapat ditanami. 

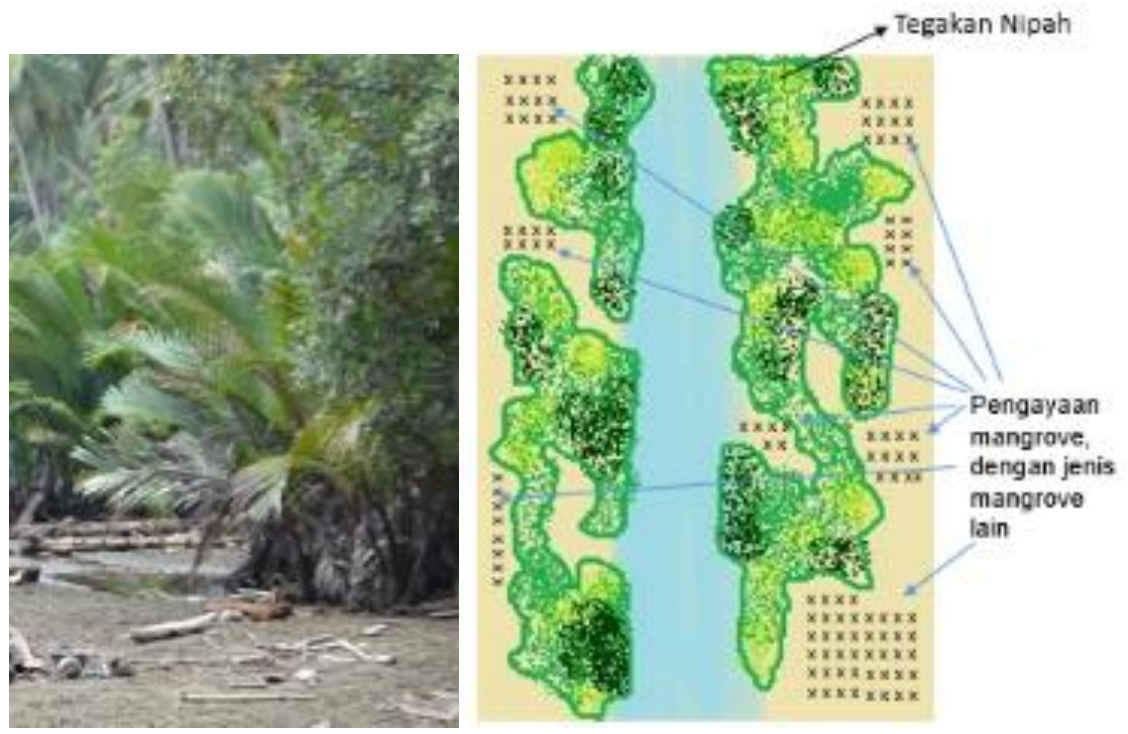

Gambar 31. Ilustrasi sederhana usulan teknis pengkayaan di tegakan nipah

2) Pengkayaan di tegakan api-api

Untuk tegakan api-api, areal sepanjang tepi sungai timur memiliki prospek untuk ditanami karena substratnya berlumpur dalam. Penanaman ini disarankan dengan jarak tanam rapat $(30 \mathrm{~cm}-50$ $\mathrm{cm}$ ), dan ditanam 2 hingga 4 lapis sesuai dengan ketersediaan ruang di sepanjang tepi sungai (lihat gambar 32). Penanaman tambahan juga dapat dilakukan di ruang kosong yang berada di tengah atau belakang tegakan api-api. Berdasarkan observasi lapangan, jumlah bibit yang ditanam tidak akan lebih dari 200 bibit. Untuk penanaman di tepi sungai, disarankan untuk memilih Rhizophora mucronata dan Rhizophora apiculata karena memiliki propagul yang panjang sehingga mampu bertahan dengan kondisi genangan sedang hingga berat. Sementara untuk penanaman di bagian tengah atau belakang tegakan, disarankan untuk menanam Rhizophora mucronata, Rhizophora apiculata, Bruguiera gymnorrhiza, Xylocarpus granatum, dan Camptostemon spp, dan beberapa jenis lainnya. Sumber bibit untuk jenis-jenis tersebut dapat diperoleh di Desa Taat atau Lokodidi.

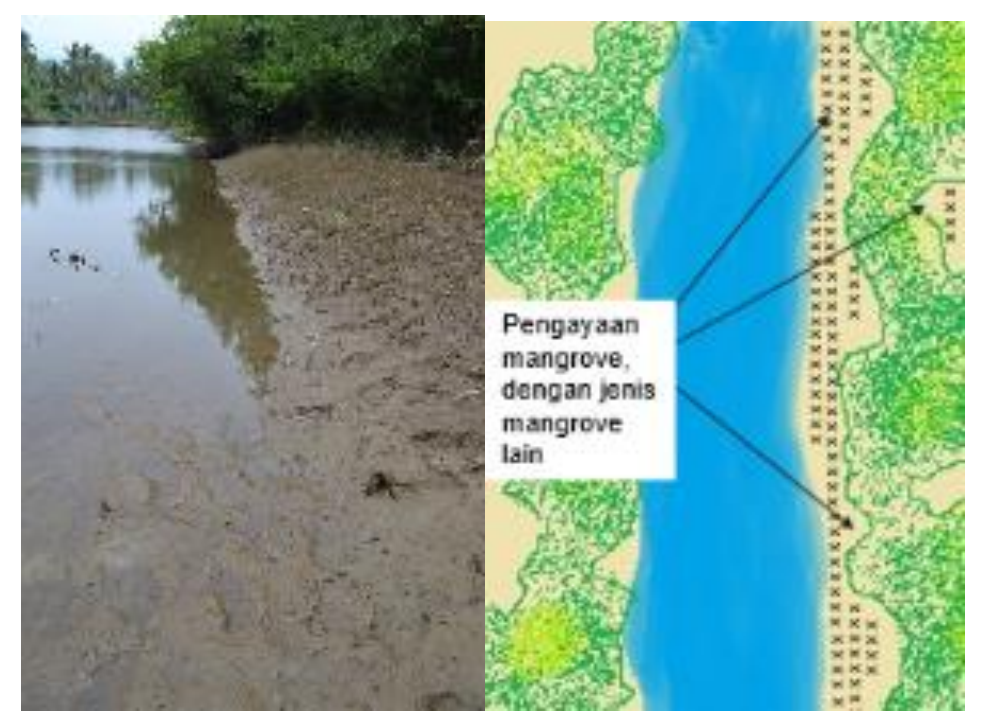

Gambar 32. Ilustrasi sederhana teknis pengkayaan di tegakan api-api 


\section{Rekomendasi tambahan: Penghijauan Desa}

Desa Taat, Lokodidi dan Matinan, masing-masing memiliki beberapa lokasi yang prospektif untuk penghijauan desa yaitu areal sepanjang kanan kiri jalan, tanah terbuka umum, dan pekarangan.

Areal kanan kiri jalan perlu dihijaukan agar sepanjang jalan menjadi lebih rindang dan menambah nilai estetika desa. Untuk lokasi ini, jarak antar bibit yang ditanam sebaiknya disarankan $5 \mathrm{~m}$ atau 10 m. Jenis tanaman yang disarankan untuk penanaman kaki jalan antara lain: Trembersi (Samanea saman), Gelodokan (Polyalthia longofolia), Mahoni (Swietenia mahagony), dan Asam jawa (Tamarindus indica).

Sementara untuk tanah terbuka, disarankan untuk menanam jenis tanaman peneduh atau yang memiliki nilai estetika antaralain Bintaro (Cerbera manghas), Erythrina spp, Ficus spp, Terminalia cattapa. Untuk penanaman ini, jarak tanam yang disarankan adalah $5 \mathrm{~m}$ x $5 \mathrm{~m}$ atau $5 \mathrm{~m}$ x $10 \mathrm{~m}$.

Sementara untuk di areal pekarangan, disarankan untuk melakukan penanam dengan jenis tanaman buah buahan, memiliki nilai ekonomis, dan digunakan secara langsung oleh masyarakat antara lain Melinjo (Gnetum gnemon), Pepaya (Carica papaya), Mangga (Mangifera indica), Kedondong (Spondias pinnata), Rambutan (Naphelium lapaceum), dan lain-lain. Jarak tanam yang diterapkan sebaiknya disesuaikan dengan ruang yang ada dan karateristik habitus tanaman.

Untuk penghijauan desa, disarakan bagi desa untuk meminta bantuan bibit dari pemerintah, terutama melalui program KBR. Dengan demikian, maka penduduk tidak perlu membuat persemaian secara khusus di desa ini. Untuk merealisasikan hal ini, diperlukan fasilitasi agar aparat Desa Matinan atau Kelompok Masyarakat dapat berkomunikasi dan berkoordinasi dengan BP DAS dan/atau Dinas Kehutanan sebagai pengelola program.

\section{Rekomendasi Teknis Pengelolaan Kegiatan}

\section{Pengelolaan kegiatan rehabilitasi}

Belajar dari pengalaman yang ada, pengelolaan kegiatan sebaiknya menghindarkan "pendekatan proyek" yang cenderung menjadikan masyarakat sebagai tenaga lepas dalam kegiatan rehabilitasi. Dalam pendekatan proyek, target yang dicapai semata-mata adalah terpenuhnya target jumlah bibit yang tertanam, bukan jumlah tanaman yang berhasil tumbuh. Hampir di banyak kasus, kegiatan pemeliharaan tidak dilakukan setelah penanaman.

Untuk program di tiga desa sasaran, sangat disarankan untuk menerapkan "pendekatan program berkelanjutan" dimana masyarakat diposisikan sebagai aktor utama yang dilibatkan secara aktif dari tahap awal hingga akhir kegiatan (perencanaan, pembibitan, penamanan, hingga pemeliharaan). Dalam kondisi ini maka masyarakat akan memiliki tanggung jawab moral untuk mencapai target yaitu banyaknya tanaman yang hidup. Untuk dapat mencapai keberhasilan maka kegiatan pemeliharaan menjadi salah satu kunci keberhasilan dalam kegiatan rehabilitasi.

Kelompok yang telah ada di masing-masing desa dinilai memiliki potensi sebagai pelaksana kegiatan. Apabila jumlah anggotanya masih kurang, hal ini bisa diatasi dengan merekrut anggota baru atau bila terpaksa bisa membentuk kelompok baru. Kelompok ini perlu mendapatan bimbingan dan fasilitasi 
dari proyek. Oleh karena itu, disarankan bagi proyek untuk merekrut fasilitator yang tinggal bersama masyarakat. Sebagai opsi, proyek bisa saja merekrut masyarakat lokal yang secara khusus ditugaskan untuk menjalankan fungsi pendampingan dan fasilitasi ini. Apabila pilihan ini yang diambil (merekrut masyarakat lokal) maka pendamping lokal ini harus mendapatkan arahan dari project dan/atau konsultan profesional.

\section{Tahapan dan tata waktu kegiatan}

Untuk merealisasikan kegiatan rehabilitasi secara utuh, diperlukan setidaknya sembilan (9) tahap kegiatan yaitu: persiapan, pelatihan, pembangunan persemaian, pembibitan, pengerasan/adaptasi tanaman, persiapan lokasi penanamam, penanaman, pemeliharaan tanaman, dan monitoring-evaluasi. Persiapan diperkirakan memakan waktu satu bulan. Sementara untuk membangun persemaian hingga mempersiapkan biibit mangrove diperlukan waktu 4.5 bulan. Sebelum ditanam di lapangan, bibit perlu diberi perlakuan "pengerasan" yaitu proses adaptasi dari suasana persemaian ke kondisi lapangan. Setelah bibit dan lokasi di penanaman dipersiapkan, penanaman bisa dilakukan sesuai dengan desain teknis yang ditentukan (sistem penanaman, jarak tanam dll). Pemeliharaan tanaman harus dilakukan secara terus menerus hingga tanaman mampu bertahan dari beberapa tekanan hama maupun gulma. Untuk mengukur keberhasilan penanaman, monitoring persentase tumbuh perlu dilakukan secara berkala.

Tabel 5. Tahapan dan tata waktu kegiatan

\begin{tabular}{|c|c|c|c|c|c|c|c|c|c|c|c|c|c|c|c|c|c|c|c|c|c|c|c|c|c|c|}
\hline \multirow{2}{*}{ No } & \multirow{2}{*}{ Kegiatan } & \multicolumn{25}{|c|}{ Minggu ke-1 } \\
\hline & & 1 & 2 & 3 & 4 & 5 & 6 & 7 & & 20 & 21 & 22 & 23 & 24 & 25 & 26 & 27 & 28 & 29 & 30 & 31 & 32 & 33 & \begin{tabular}{l|l|}
.. & 40
\end{tabular} & \begin{tabular}{|l|l|}
.. & 64 \\
\end{tabular} & dst \\
\hline 1 & Persiapan & & & & & & & & & & & & & & & & & & & & & & & & & \\
\hline 2 & Pelatihan & & & & & & & & & & & & & & & & & & & & & & & & & \\
\hline 3 & Pembangunan persemaian & & & & & & & & & & & & & & & & & & & & & & & & & \\
\hline 4 & Pembibitan* & & & & & & & & & & & & & & & & & & & & & & & & & \\
\hline 5 & Pengerasan & & & & & & & & & & & & & & & & & & & & & & & & & \\
\hline 6 & Persiapan lokasi penanaman & & & & & & & & & & & & & & & & & & & & & & & & & \\
\hline 7 & Penanaman & & & & & & & & & & & & & & & & & & & & & & & & & \\
\hline 8 & Pemeliharaan & & & & & & & & & & & & & & & & & & & & & & & & & \\
\hline 9 & Monitoring & & & & & & & & & & & & & & & & & & & & & & & & & \\
\hline
\end{tabular}

\section{Pelatihan}

Kegiatan ini sangat diperlukan mengingat kapasitas teknis masyarakat dalam kegiatan rehabilitasi masih rendah. Setidaknya terdapat tiga topik pelatihan yang perlu diberikan kepada masyarakat yaitu : 1) pengadaan benih-anakan, 2) persemaian-pembibitan, dan 3) penanaman-pemeliharaan (termasuk teknik monitoring tanaman). Nara sumber dalam pelatihan ini sebaiknya yang benar-benar berpengalaman di lapangan, dengan kemampuan teknis yang tinggi, serta mampu berkomunikasi dengan masyarakat. 


\section{Pembibitan mangrove}

Pembangunan persemaian hanya dilakukan apabila diputuskan bahwa penanaman menggunakan bibit berpolibag (bukan penanaman propagul secara langsung di lapangan). Mengingat ancaman ternak, maka persemaian harus dilindungi dengan pagar. Kriteria lokasi yang tepat untuk persemaian adalah sebagai berikut:

- Tanah berlumpur

- Terkena pasang surut air laut

- Topografi datar

- Dekat dengan lokasi penanaman

- Lokasi mudah dijangkau

- Dekat dengan sumber media

Jumlah yang dibibitkan harus disesuaikan dengan jumlah koloni yang akan dibuat atau berapa jumlah total tanaman yang akan ditanam. Untuk keperluan penyulaman, jumlah yang dibibitkan sebaiknya dilebihkan $20 \%$.

Salah satu kunci dalam keberhasilan pembibitan adalah penggunaan benih atau propagul yang masak dan berkualitas tinggi. Buah yang masak untuk setiap jenis mangrove memiliki ciri-ciri yang berlainan satu sama lain. Tabel 7 di bawah ini menjelaskan ciri-ciri kemasakan benih/propagul beberapa jenis mangrove yang umum ditanam.

Tabel 6. Ciri-ciri buah/benih yang masak

\begin{tabular}{clll}
\hline No & \multicolumn{1}{c}{ Jenis } & & \multicolumn{1}{c}{ Ciri-Ciri buah masak } \\
\hline 1 & Bakau (Rhizophora sp.) & $\bullet$ & $R$. Mucronata: kotiledon berwarna kuning, panjang $\pm 50 \mathrm{~cm}$ \\
& & - $R$. Apiculata: kotiledon berwarna merah kekuningan, panjang $\pm 20 \mathrm{~cm}$ \\
\hline 2 & Cengal (Ceriops tagal) & Kotiledon telah tumbuh sepanjang $1-1,5 \mathrm{~cm}$, panjang buah $\pm 20 \mathrm{~cm}$ \\
\hline 3 & $\begin{array}{l}\text { Tanjang (Bruguiera } \\
\text { gymnorrhiza) }\end{array}$ & Kotledon berwarna coklat kemerahan, panjang buah $\pm 20 \mathrm{~cm}$ \\
\hline 4 & Pedada (Sonneratia spp.) & Diamater buah $\pm 40 \mathrm{~mm}$, terapung di air \\
\hline 5 & Api-api (Avicennia marina) & Warna buah hijau kekuningan \\
\hline
\end{tabular}

Untuk jenis bakau (Rhizophora spp., Ceriops spp., Bruguiera spp.), perendaman buah/propagul selama 5-10 hari di air payau sangat disarankan. Selain dapat mempercepat proses perkecambahan dan meningkatkan prosentase hidup tanaman, buah akan terhindar dari serangan hama ketam atau kepiting.

\section{Penanaman}

Penanaman sebaiknya dilakukan saat musim timur dimana kondisi ombak relatif tenang. Waktu tanam sebaiknya dilakukan pada saat air laut surut agar bibit mudah sampai ke lokasi tanam. Penanaman harus dilakukan sesuai dengan desain teknis yang telah ditetapkan, termasuk pengaturan jarak tanam. Dalam penanaman, harus dipastikan bahwa plastik polibag di lepas dari bibit sebelum ditanam. 


\section{Pemeliharaan dan monitoring}

Untuk kehidupan tanaman mangrove, penyiraman sebenarnya tidak terlalu penting karena lokasi penanaman pada umumnya telah terkena pasang surut. Namun demikian, penyiraman sebaiknya tetap dilakukan untuk pencegahan hama dan penyakit. Penyiraman dilakukan dengan menggunakan air payau dan difokuskan pada bagian daun dan batang. Banyak sekali kejadian dimana serangga meletakkan telurnya di batang atau daun, dan kemudian menetas menjadi ulat yang memakan bagian tanaman. Dengan adanya penyiraman air payau secara rutin maka ancaman hama ulat ini dapat dihindari.

Monitoring tanaman perlu dilakukan untuk mengetahui kondisi tanaman setelah ditanam dan mengukur keberhasilan tumbuh tanaman. Pada umumnya, monitoring ini dilakukan 3 bulan setelah penanaman. Apabila ada tanaman yang mati, maka penyulaman perlu dilakukan untuk meningatkan keberhasilan tumbuh tanaman. Penyulaman ini dilakukan dengan cara mengganti tanaman yang mati dengan bibit baru.

\section{Rekomendasi umum lain}

\section{Pembuatan Peraturan Desa}

Masing-masing desa disarankan untuk membuat Peraturan Desa (Perdes). Perdes ini diharapkan mampu untuk mengatasi berbagai permasalah lingkungan yang ada di desa masing-masing (misalnya penambangan pasir di Matinan). Lebih jauh, Perdes diharapkan juga mampu melindungi keberlangsungan kegiatan rehabilitasi di masa mendatang, serta mengatur tata kelola Sumber Daya Alam (SDA) di desa secara bijaksana dan berkelanjutan.

\section{Optimalisasi POKJA DAS}

Saat ini, Kelompok Kerja Mangrove Daerah (KKMD) di Kabupaten Buol belum terbentuk. Sementara di lapangan, berbagai permasalahan dan tantangan terkait dengan ekosistem mangrove semakin kompleks. Atas dasar inilah maka keberadaan KKMD di Buol sangatlah dibutuhkan. Namun untuk membentuk KKMD tidaklah mudah. Dibutuhkan waktu dan proses yang cukup lama untuk dapat membentuk institusi ini. Untuk menghadapi situasi saat ini, direkomendasikan untuk mengoptimalkan peran POKJA yang telah ada. POKJA diharapkan dapat secara proaktif mengurusi berbagai hal yang terkait dengan mangrove. Dengan demikian maka peran yang seharusnya dilakukan oleh KKMD akan dapat tertangani oleh POKJA.

\section{Pencegahan konversi mangrove dari dampak pembangunan jalan (Kasus desa Lokodidi)}

Terkait dengan rencana lanjutan proyek pembangunan jalan di Desa Lokodidi, perlu kiranya dilakukan upaya-upaya agar hutan mangrove desa Lokodidi tidak terkena dampak dari proyek ini. Koordinasi dan komunikasi dengan para pihak (terutama PU, Dishut, dan BAPPEDA-PM) perlu difasiltasi agar diperoleh solusi yang tepat untuk proyek ini tanpa mengorbankan hutan mangrove. 


\section{Lampiran}

Lampiran 1. Daftar vegetasi yang dijumpai selama observasi di sepanjang pesisir

\begin{tabular}{|c|c|c|c|c|c|c|}
\hline \multirow{2}{*}{ No } & \multirow{2}{*}{ Jenis } & \multirow[t]{2}{*}{ Nama Indonesia } & \multirow[t]{2}{*}{ Nama lokal } & \multicolumn{3}{|c|}{ Desa } \\
\hline & & & & Matinan & Taat & Lokodidi \\
\hline A & Mangrove & & & & & \\
\hline 1 & Sonneratia alba & $\begin{array}{l}\text { Pedada putih/ } \\
\text { Perepat }\end{array}$ & Payapat & + & ++ & ++ \\
\hline 2 & Sonneratia caseolaris & $\begin{array}{l}\text { Pedada merah/ } \\
\text { perepat merah }\end{array}$ & & $\mathrm{O}$ & ++ & ++ \\
\hline 3 & Sonneratia ovata & Pedada/ Kedabu & & 0 & 0 & + \\
\hline 4 & Bruguiera gymnorrhiza & Lenggadai/ Tanjang & Tonggi & + & ++ & ++ \\
\hline 5 & Avicennia marina & Api-api Jambu & Peoapi & ++ & ++ & ++ \\
\hline 6 & Rhizophora apiculata & $\begin{array}{l}\text { Bakau sedang/ } \\
\text { Bakau minyak }\end{array}$ & & 0 & ++ & ++ \\
\hline 7 & Rhizophora mucronata & $\begin{array}{l}\text { Bakau besar/ Bakau } \\
\text { hitam }\end{array}$ & & + & ++ & ++ \\
\hline 8 & Nypa fruticans & Nipah & Kibuy & ++ & ++ & ++ \\
\hline 9 & Ceriops tagal & Tengal/ Cengal & Tanga & + & +++ & ++ \\
\hline 10 & Xylocarpus granatum & Nyiri & & 0 & + & ++ \\
\hline 11 & Dolicandhron spatacae & & & $\mathrm{O}$ & + & + \\
\hline 12 & Acanthus ilicifolius & Jeruju & Tuwele & + & + & + \\
\hline 13 & Camptostemon sp.1 & & & 0 & + & ++ \\
\hline 14 & Camptostemon sp.2 & & & 0 & 0 & + \\
\hline
\end{tabular}

\begin{tabular}{|c|c|c|c|c|c|c|}
\hline B & Mangrove ikutan & & & & & \\
\hline 1 & Derris trifolia & Tuba Laut & Tali hutan & ++ & ++ & ++ \\
\hline 2 & Hibiscus tiliaceus & Waru Lengis & Barlau & +++ & + & + \\
\hline 3 & Terminalia cattapa & Ketapang & Tolite & ++ & + & + \\
\hline 4 & Ipomea pes caprae & $\begin{array}{l}\text { Galaran/ Tapak } \\
\text { Kuda }\end{array}$ & Buahring & ++ & + & + \\
\hline 5 & Cerbera manghas & Bintaro & Lingayung & ++ & + & + \\
\hline 6 & Pandanus tectorius & Pandan Besar & - & + & + & + \\
\hline 7 & Pongamia pinnata & Malapari/ Dasapri & & ++ & + & 0 \\
\hline
\end{tabular}

\begin{tabular}{lllllll}
\hline C & \multicolumn{2}{l}{ Tumbuhan pantai daratan } & & & \\
\hline 1 & Gliciridia sepium & Gamal & $\begin{array}{l}\text { Kayu } \\
\text { manado }\end{array}$ & ++ & + & + \\
\hline 2 & Lannea coromandelica & $\begin{array}{l}\text { Kayu jawa/ Kayu } \\
\text { kuda }\end{array}$ & Kayu jawa & + & + & + \\
\hline 3 & Alstonia anguistiloba & Pulai & - & + & 0 & 0 \\
\hline 4 & $\begin{array}{l}\text { Dendrolobium } \\
\text { umbellatum }\end{array}$ & Kanyere Laut & - & + & + & + \\
\hline 5 & Crotalaria striata & Orok-orok Sapi & - & + & + & + \\
\hline 6 & Indigofera suffruticosa & Nila/tarum & - & + & + & + \\
\hline 7 & Calotropis gigantea & Biduri & - & + & + & + \\
\hline
\end{tabular}




\begin{tabular}{clllccc}
\hline \multirow{2}{*}{ No } & & Jenis & Nama Indonesia & Nama lokal & & Desa \\
\cline { 5 - 6 } & & & & Matinan & Taat & Lokodidi \\
\hline 8 & Clerodendrum inerme & Gambir laut & - & + & + & + \\
\hline 9 & Hernandia peltata & Kempis Laut & - & + & 0 & 0 \\
\hline 10 & Peltophorum spp & Soga & Tombilit & ++ & + & ++ \\
\hline 11 & Ficus septica & Awar-awar & - & + & 0 & 0 \\
\hline 12 & Cyperus sp. & Teki & - & + & + & + \\
\hline 13 & Leea indica & Girang Merah & - & + & + & 0 \\
\hline 14 & Passiflora foetida & Rambusa & - & + & 0 & 0 \\
\hline 15 & Erythrina variegata & Dadap laut & - & + & 0 & 0 \\
\hline
\end{tabular}

\begin{tabular}{|c|c|c|c|c|c|c|}
\hline D & Tanaman budidaya da & pakarangan & & & & \\
\hline 1 & Cocos nucifera & Kelapa & Bongo & ++++ & ++ & ++ \\
\hline 2 & $\begin{array}{l}\text { Artocarpus } \\
\text { heterophylus }\end{array}$ & Nangka & - & ++ & + & + \\
\hline 3 & Aleurites moluccana & Kemiri & Kemiri & + & + & + \\
\hline 4 & Mangifera indica & Mangga & - & ++ & + & + \\
\hline 5 & Citrus maxima & Jeruk Bali & - & + & + & + \\
\hline 6 & Nephelium lapaceum & Rambutan & - & + & + & + \\
\hline 7 & Artocarpus incises & Sukun & - & + & + & + \\
\hline 8 & Morinda citrifolia & Mengkudu & - & + & + & + \\
\hline 9 & Theobroma cacao & Kakao/ coklat & - & + & + & + \\
\hline 10 & Coffea canephora & Kopi & - & + & + & + \\
\hline 11 & Spondias pinnata & Kedondong & - & + & + & + \\
\hline 12 & Musa spp. & Pisang & - & + & + & + \\
\hline 13 & Syzygium malaccense & Jambu bol & - & + & + & + \\
\hline 14 & Areca cathecu & Pinang & - & + & + & + \\
\hline 15 & Pterocarpus indicus & Angsana & - & ++ & + & + \\
\hline 16 & Jatropha curcas & Jarak pagar & - & + & + & + \\
\hline 17 & Polyaltha longifolia & Glodokan & - & ++ & + & + \\
\hline 18 & Durio zibethinus & Durian & Durian & ++ & + & + \\
\hline 19 & Coffea arabica & Kopi & Kopi & + & + & + \\
\hline 20 & Carica papaya & Pepaya & Pepaya & + & + & + \\
\hline 21 & Myristica fragrans & Pala & Pala & + & + & + \\
\hline 22 & Syzygium aromaticum & Cengkeh & Cengkeh & ++ & ++ & ++ \\
\hline
\end{tabular}

\begin{tabular}{clllccc}
\hline E & Tumbuhan Rawa & & & & & ++ \\
\hline 1 & Metroxylon sagu & Sagu & - & ++ & ++ \\
\hline 2 & Flagellaria indica & Owar & - & + & + & + \\
\hline 3 & Phragmites karka & $\begin{array}{l}\text { Perumpung/ } \\
\text { Bayongbong }\end{array}$ & - & + & + & + \\
\hline 4 & Acanthus ilicifolius & Jeruju & - & + & + & + \\
\hline 5 & Acrostichum aureum & Paku laut & - & + & + \\
\hline
\end{tabular}

